\title{
The long prehistory of ethnographic film
}

$\mathrm{T}$ HE half-century running from the mid-I89os, when moving image camera technology was first developed, to the period of the Second World War in the I940s constitutes over a third of the total time-span of ethnographic film-making. This was a period of tentative beginnings, sporadic activity and blurred genres. Though a large number of films made during this period could be said to possess a certain degree of 'ethnographicness' - as defined in the General Introduction to this book - many of these were not produced by academic film-makers, but by commercial production companies, government or colonial agencies, even private individuals. Ethnographic film in the form in which it is most frequently encountered today barely existed, even though the first seeds of later developments were evident. Borrowing a phrase from the distinguished Belgian anthropologist and film-maker, Luc de Heusch, in this chapter I refer to this long period of gestation as the 'prehistory' of ethnographic film. ${ }^{1}$

Throughout this prehistory, indeed until as late as the I970s, in the academic ethnographic film-making literature, the moving image camera was routinely compared to the hero instruments of the scientific world, the telescope and the microscope particularly, and its function was seen as being to provide an entirely objective registration of reality. Academic film-makers did not aim to produce documentary films in the modern sense, that is, non-fiction films structured around a central narrative, but rather films of documentation. In the ideal case, these documentation films would provide a detailed visual record of given events and situations, and would be executed in the most objective manner possible. Although they might later be edited and reordered in a particular way to support a verbal presentation, sometimes with the addition of explanatory intertitles, there was typically no attempt to build a narrative directly out of the visual material itself.

In fact, the primary purpose of documentation film-making was not for public presentation as such but rather for research, taking advantage of the previously unparalleled mimetic capabilities of the technology and the possibility it offered to observe the same event or situation in detail over 
and over again. The ultimate goal was to build up great archives of visual records of human behaviour that could be analysed for scientific purposes in perpetuity, either by the film-makers themselves or by third parties.

This documentation film-making was also closely tied up with 'salvage' ethnography objectives, that is, the preservation of a record of cultural phenomena threatened with extinction due to social and political change. As the effects of technological and political modernisation spread ever deeper over the course of this period into previously isolated mountain valleys, tropical rainforests and deserts across the globe, communities living in these regions found themselves undergoing a qualitatively greater degree of social and cultural change than they had experienced in millennia. The effects of this change were often highly negative: many communities were dispersed or decimated, some entirely destroyed. In almost all cases, elaborate and often aesthetically beautiful cultural practices, developed and honed over generations, were abandoned as they lost their meaning or purpose. Ethnographic film-makers were intensely aware of these processes and sought through their work to preserve a record of these vulnerable cultural practices for future generations. But anything that hinted at authorship in this form of film-making was thought to compromise the archival value of the material recorded.

The reluctance within academia over this period to engage in any kind of authorial transformation of the material generated by the moving image camera was in marked contrast to the enthusiasm and inventiveness with which film-makers from the emergent cinema industry embraced all manner of authorial devices as a means of representing the cultural diversity of the world. Although their motives may have been commercial and their primary goal merely to provide entertainment, these extra-academic film-makers generated an account of the great cultural changes taking place during the early twentieth century that far excedes in both quantity and complexity the modest film record left behind by academic ethnographers.

The number of films made prior to the Second World War that might be considered to possess at least some degree of ethnographicness is vast. If one were to adopt a definition of ethnography in accordance with the standard modern-day usage, we would have to admit films made in any part of the world into this prehistory. But that would have made this account even more substantial than it is already is. To keep it within manageable proportions, I therefore consider only films made by Europeans or filmmakers of European descent about 'other cultures'. While this is clearly unsatisfactory in many regards, it is a choice that can at least be defended on the grounds that this would have been the primary denotatum of the domain of the 'ethnographic' in the period to which my account refers.

I shall further restrict the ground to be covered in this first chapter by reserving a discussion of the most commercial and popular forms of film-making of 
ethnographic interest to Chapter 2. Though the distinction between commercial and non-commercial film-making in this period is often hazy, in this chapter I am primarily concerned with films that had, at most, limited commercial objectives, and which fall into three broadly overlapping categories: films that were made for the purposes of academic research, films made for museums and, finally, films made for a range of purposes associated with state-funded empire- and nation-building projects that aimed at inventorising and co-opting the culture of First Nations or other indigenous groups.

Even with these restrictions, I can only consider a very limited number of examples. However, I shall frequently direct readers to The Silent Time Machine, a website that I have prepared about early ethnographic film, which not only provides more extensive details about individual films but also links through which many of these films are viewable. ${ }^{2}$

\section{The first ethnographic Research Films: Regnault, Haddon, Spencer}

Although the makers of the earliest ethnographic research films might have aspired to use the moving image camera to provide entirely objective accounts of the world, their works invariably involved what one might call 'on-request performances', that is, performances that the subjects put on specifically because the film-makers had asked for them. This was inevitably the case since such were the limitations of the technology of the time that it was impossible for a film to be shot without the active collaboration of the subjects, be it to ensure that filming was taking place at a location where there was adequate lighting, or simply to guarantee that they kept within the field of view of the camera. The notion of filming people going about their business without taking into account the camera's presence was simply not realisable at that time. But in making a request to the subjects to perform a particular action in a particular place, early ethnographic film-makers, despite themselves, were in effect engaged in an act of authorship.

The footage that is often said to represent the very first example of moving images produced specifically for ethnographic research purposes certainly involved a series of 'on-request performances' of this kind. This is the material shot by the French anatomist Félix-Louis Regnault and his assistant, Charles Comte, in the spring of I 895 , which consists primarily of short sequences of Africans moving in various ways - walking, sitting, running, jumping and climbing trees - and engaging in certain technical activities. These sequences were not filmed in Africa, however, but in Paris, either at a colonial exhibition beside the Eiffel Tower, or in the laboratory of Étienne-Jules Marey, Regnault's mentor. Marey had not only introduced Regnault to the study of human and animal locomotion but was also the 
designer of the 'chronophotographic rifle', the cinematographic device used by Regnault and Comte. ${ }^{3}$

At the time that he shot these sequences, Regnault was concerned to explore the relationship between bodily movement and racial identity, since the concept of race remained central to the still-dominant evolutionary theoretical paradigm in anthropology. Within a few years, however, in accordance with changes going on more generally in anthropological theory at that time, Regnault had replaced this physiological notion of race as a determining variable in his theories with that of 'ethnie', a category defined rather in terms of cultural and linguistic criteria. In this latter form, his work anticipates the ideas of both Marcel Mauss and Franz Boas concerning the way in which cultural tradition may be inscribed in bodily movement. ${ }^{4}$

The sequences shot by Regnault were recorded onto strips of sensitised paper and could not therefore be projected. But his aim was not to make a film to show to an audience, but rather to assemble a series of sequences that could later be minutely inspected by academics interested in modes of locomotion. To improve visibility, the subjects filmed in Marey's laboratory were asked to walk in front of a white sheet, while to one side, in some of the sequences, there is a large chronometer presumably intended to allow the viewer to monitor the speed of the subjects' movements. Regnault would later envisage a magnificent future when a great collection of such supposedly objective filmic 'documents' had been assembled and an anthropologist would have 'in his drawer' a dossier of all the many different forms of human locomotion. This dossier would allow him, whenever he pleased, not merely to observe such banal actions as squatting and climbing trees, but also to 'be present at feasts, at battles, at religious and civil ceremonies, at different ways of trading, eating, relaxing' 5

The earliest ethnographic research films to be shot actually in the field similarly involved 'on-request performances'. Here the first example is generally taken to be the four minutes of footage shot by Alfred Haddon on the island of Mer (formerly Murray Island) in the Torres Strait, an archipelago lying between northern Australia and New Guinea. In modern geopolitical terms, the Strait forms part of Australia, but in cultural terms the Mer islanders are Melanesian rather than Aboriginal.

Haddon was a zoologist from the University of Cambridge, and he had come to Mer as the leader of a multidisciplinary anthropological expedition. He used a Newman and Guardia kinematograph, an early hand-cranked camera manufactured in Britain that had been modelled on the cinématographe first introduced by the Lumière brothers in France in I895. The film stock that Haddon used, which cost more to buy than the equipment, was $35 \mathrm{~mm}$, the standard gauge of most early moving image cameras. Haddon's diary indicates that he shot the film material shortly before the expedition was due to leave Mer, in early September I898. 
These four minutes of footage show a series of performances by small groups of three or four men, mostly of dancing, but also including one short sequence of traditional fire-making, all carried out at Haddon's request. The most striking part of this material, and seemingly the very last to be shot, is a 45 -second take showing three men re-enacting a dance that had once formed part of a secret male initiation ceremony connected with the Mer culture-hero, Malo-Bomai. Under pressure from missionaries, this ceremony had long been abandoned, certainly as a public spectacle. The masks traditionally worn for this part of the ceremony had been made of finely crafted turtle shell and had been decorated with the jawbones of enemies killed in inter-island warfare. As these masks had all been destroyed at missionary insistence, Haddon had to cut up the expedition's cardboard packing cases in order to supply the performers with the wherewithal to recreate them. But even though the masks were made of cardboard, and the dancing was merely a re-enactment, the performers were very concerned that no woman on the island should even see the masks, let alone the performance (figure I.Ia). ${ }^{6}$

Three years later, acting on Haddon's advice, Baldwin Spencer, a biologist and former art student, originally from Manchester, who had been appointed to a chair at the University of Melbourne, took a moving image camera on his renowned expedition with Frank Gillen across Central Australia in I90I-2. 'You really must take a Kinematograph', Haddon had counselled, 'it is an indispensible piece of anthropological apparatus'. In this turn of phrase, Haddon neatly encapsulated the then-current idea of the moving image camera as an instrument of the same kind as one might find in a scientific laboratory. ${ }^{7}$ Spencer used a Warwick kinematograph to film some 50 minutes of ritual and ceremonial dancing performed by the Arrernte, an Aboriginal people, then often referred to as the 'Aranda', who live in the region around Alice Springs. This was a considerable advance on Haddon's efforts, not only in terms of sheer duration, but also - possibly due to Spencer's early training as an artist - in terms of both content and technique.

Most of Spencer's material concerned ritual events that the Arrernte consider secret and sacred and which should therefore be witnessed only by initiated adult men. For this reason, the present-day Arrernte have asked that access to this material be restricted, so most of Spencer's footage can no longer be viewed by the general public. However, one part of Spencer's footage shows a ceremony known as the tjitjingalla, which was a 'corroboree', that is, a form of ceremonial dancing that is not considered sacred and which is therefore open to everyone, including Aboriginal women and children, as well as all outsiders.

Although the tjitjingalla filmed by Spencer was more authentic than the initiation ceremony dance filmed by Haddon, in the sense that it was still being actively practised by the subjects for their own reasons, the particular 


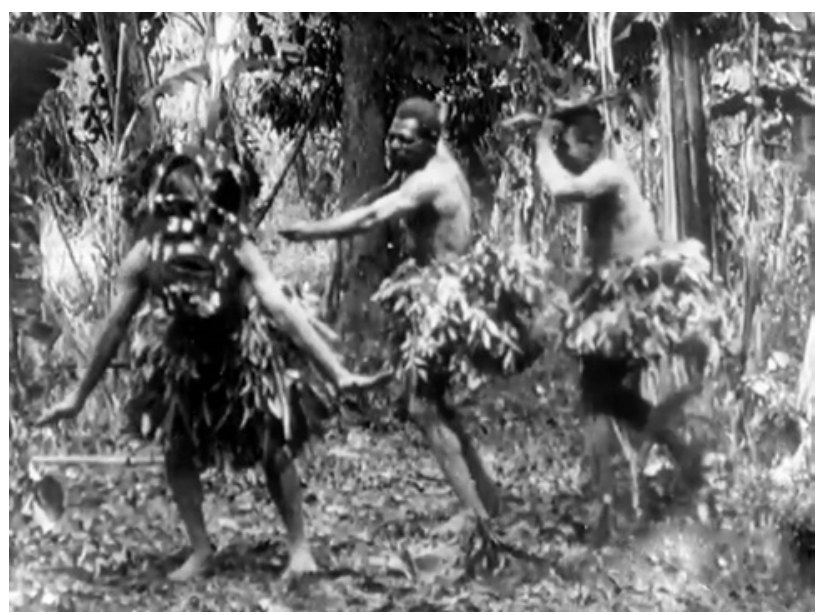

(a) Mer Islanders recreate the journeys of the culture-hero Malo in the form of a shark in a dance traditionally performed at a male initiation ceremony. Unnoticed by Haddon, the lead dancer's hands evoke a shark's dorsal fins while all three dancers appear to be wearing imitations of women's skirts.

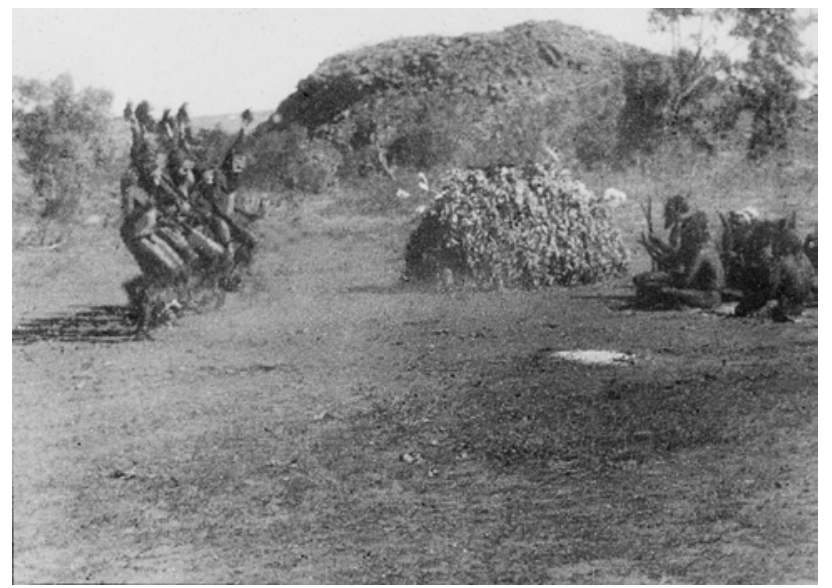

(b) Though barely visible in this still, the tjintjingalla dancers, left, carry dance sticks entwined with human hair. The white feathers sticking out of the brushwood shelter in front of them are attached to large prongs that the dancers subsequently positioned around their necks so that they looked 'like horned cattle'. Spencer could not discover the meaning of these dances, but subsequent research suggests they enact a then-recent massacre of Aborigines by police armed with carbines (the dance sticks) and a millenarian ritual aimed at ridding the country of Europeans and their cattle (the feathered prongs).

I. I Alfred Haddon and Baldwin Spencer - unwitting witnesses. 
performance of the tjintjingalla that Spencer filmed, neverthless, involved his direct authorial intervention: normally the tjitjingalla dances were performed at night, but having no means of artificial lighting, Spencer had to ask for what he called 'rehearsals' to be performed during the day instead. ${ }^{8}$

Considered as works of objective documentation, the films of Haddon and Spencer are clearly compromised in a number of respects. Not only were the performances put on explicitly at the request of the film-makers, but they were performed outside their normal social contexts and in a very abbreviated and reduced form. Even so, when these films are assessed in the light of the comparative ethnography and the historical accounts that have been published subsequently, they can yield valuable insights into the way of life of the subjects, some aspects of which would not have been available to the film-makers themselves.

Thus, for example, without his being aware of it, Haddon's material appears to show that there was an element of transvestism in the traditional male initiation ceremony on Mer in that the dancers seem to be wearing voluminous skirts that imitate the kind normally then worn only by women. If so, this feature would link the Mer ceremony to the discussion of the mobile and socially constructed nature of gender identity in Melanesia that has held a prominent place in the regional ethnographic literature in recent years. Spencer, for his part, equally unwittingly, in filming the tjitjingalla appears to have recorded what some subsequent authors have identified as an Aboriginal millenarian dance whose purpose was to rid the country of European settlers and their cattle by ritual means. If this is indeed the case, Spencer's film offers early visual evidence of the Aboriginal will to resist invasion which has ensured the continuation of their culture and identity to this day, entirely contrary to Spencer's own expectations (figure I.Ib). ${ }^{9}$

The textual publications that arose from these two expeditions had an immense impact on the developing academic discipline of anthropology. In contrast, although they are now considered very significant in the history of ethnographic film, their films had no such immediate impact. Haddon appears to have made only very limited use of his film material, be it for scientific research or for public projection, and while Spencer did later use his footage - in an ethically dubious fashion - in a series of very well attended public lectures, and also alluded to it in his popular writings about his 'wanderings in wild Australia', he never made them the focus of an explicitly academic discussion. There is no evidence that either Haddon or Spencer ever encouraged their academic protegés to follow in their footsteps as film-makers.

For the next six decades, ethnographic film-making by English-speaking anthropologists in the British sphere of academic influence was no more than a sporadic activity. David MacDougall has called this period the 'dark 
age' of visual anthropology. ${ }^{10}$ In large measure, this came about because the cost and logistical difficulties of making films were simply too great relative to the perceived academic benefits. In the I929 edition of Notes and Queries, the fieldwork manual published periodically by the Royal Anthropological Institute in London, the entry relating to film-making runs to no more than two pages - only half the number dedicated to the collection of string figures. Under the by-then anachronistic title, 'Kinematography', the filmmaking entry begins with the observation that: The kinematograph, invaluable as it is for giving a record of the life of native peoples, involves difficulties which make its use not very practicable in most scientific expeditions.' Principal among the 'difficulties' listed were the cost of the camera and film stock. It seems very likely that this entry was written by none other than Alfred Haddon, but whoever the author, the decline in perceived importance is notable: what had once been 'indispensible' had now become 'not very practicable'. 11

Although the Notes and Queries entry alludes only to cost considerations, there was undoubtedly more than mere lack of resources to this decline in interest in ethnographic film-making. For if film-making had been thought to make a significant contribution to the generation of anthropological knowledge, no doubt the resources would have been found to support it. The most widely accepted view is that this decline in interest was primarily a consequence of changing ideas about the goals of anthropology as an academic discipline and, concomitantly, about the kind of fieldwork that was necessary to produce the results that this new conception of the discipline required.

Haddon and Spencer had made their films in an era when anthropological fieldwork still consisted of expeditions modelled on the field trips of natural scientists. In this expeditionary format, researchers typically kept on the move, never remaining long enough in any one place to learn the language of the subjects of study. It was also strongly associated with the collection of material objects, mostly artefacts, but also sometimes human body parts, which could then be taken back and examined in greater detail in university laboratories in the metropoli before eventually being displayed to the general public in museums.

Cinematography, like still photography before it, had initially been welcomed by anthropologists as a means of collecting reliable and transportable visual records of technical processes and ceremonial performances as practised in their original environments. These visual media also first became available at a time when evolutionary theoretical paradigms that laid a particular emphasis on the relationship between race and culture were still influential in academic anthropology. In this context, both photography and cinematography provided a convenient way of documenting the external characteristics of the subjects - be it in relation to physiology or to modes of 
dress and self-decoration - that served to define the racial and cultural categories that were central to these evolutionary theories.

But from around I9Io, the itinerant expeditionary model of fieldwork was gradually displaced in English-language anthropology by the intensive study of one particular community based on an extended period of first-hand participant-observation of day-to-day life and competence in the local language. Meanwhile, race as a category of theoretical analysis also progressively lost its prominence in the early years of the new century: rather than seeking to relate cultural practices to racial identity and evolutionary stages, anthropologists sought instead to explain them in terms of social organisation, more general cultural principles or relationships with the natural environment. This new intellectual orientation and method of carrying out fieldwork was paradigmatically exemplified by the work of Bronislaw Malinowski on the Trobriand Islands at the time of the First World War, as discussed in the General Introduction to this book. ${ }^{12}$

As a result of these changes, it has been argued, the importance of detailed textual accounts of systems of belief and social organisation increased and the collecting of material objects correspondingly diminished. This change in emphasis also coincided with a move towards the establishment of departments of anthropology in universities, where there was typically greater interest in social theory than in material objects. As the interest in collecting declined, so too did the importance of photography and cinematography, both as technologies of fieldwork and as a means of presenting the results. Certainly, neither photography nor cinematography is mentioned in Malinowski's famous discussion of ethnographic fieldwork methods in the Introduction to Argonauts of the Western Pacific. ${ }^{13}$

Yet while these arguments may hold good for the practice of ethnographic film-making in university departments in Britain, elsewhere ethnographic film-making often took place in association with museums or similar institutions, for whom the ethos of collecting remained important. Another major motivation for making ethnographic films during this period, and which often overlapped with museum-based film-making, were colonial or nation-building projects of various kinds that aimed at inventorising the culture of First Nations and other indigenous groups. It is to these forms of ethnographic film-making that I now turn.

\section{ETHNOGRAPHIC FILM-MAKING IN THE EUROPEAN COLONIAL empires: German, French, British}

Among European nations maintaining global colonial empires in the early years of the twentieth century, one of the most active producers of films of ethnographic interest was Germany. In the very first years of the twentieth 
century, anthropologists in Germany were enthusiastic early adopters of the phonograph for recording music and language in the field and it has even been suggested that their interest in moving image cameras was initially to make films that could accompany their recordings rather than being merely an extension of an interest in photography, as was generally the case elsewhere. $^{14}$

After the First World War, Germany would be deprived of its overseas colonies by the Treaty of Versailles, and German ethnographic film-making outside Europe would decline markedly. But for a ten-year period before the war, film-makers associated with German ethnographic museums and other academic institutions were particularly active in the German colonies in Africa and Melanesia. Like Haddon and Spencer before them, these early German ethnographic film-makers were not aiming to produce documentaries as they would be understood today. Rather their goal was to use the moving image camera to document cultural phenomena in the most objective possible fashion.

One of the first to do so was Karl Weule of the Leipzig Ethnological Museum, who made a series of short films about dance during the course of an expedition in 1906 to Lindi, in what is now southern Tanzania but was then the German colony of Tanganyika. Shortly afterwards, in I908-IO, two different German expeditions to Melanesia also came back with film material: one was the Hamburg Museum expedition to various islands in Micronesia and the then German colony of Neu-Guinea on the northern coast of present-day Papua New Guinea, while the other was the expedition of Richard Neuhauss, supported by the Berlin Society for Anthropology, Ethnology and Prehistory, also to the northern coast of Neu-Guinea. However, none of these researchers had any training or experience as film-makers and the equipment that they were using was very primitive. Not surprisingly therefore, the results were very modest, both in a technical sense and in terms of content: the material consists almost entirely of very brief shots of crafts or ceremonies. In no case did these film-makers produce more than around 40 minutes of footage. Only a fraction of this material has survived or has proved viewable. ${ }^{15}$

Much the same has to be said for the material shot in I9I I by the great German Amazonist anthropologist Theodor Koch-Grünberg in Koimelemong, a mixed Taulipang-Wapishana village in Roraima in northern Brazil, close to the frontier with Venezuela. The subject matter consists of the usual staples of the time: technical processes and a ceremonial dance. These probably constitute the very first moving images of the indigenous peoples of the Amazon Basin but they certainly cannot be described as great works of cinematographic art. Although Koch-Grünberg was a talented photographer, his lack of experience as a film-maker is only too evident: the framing is sometimes so poor that the subjects are only just within the field of vision 

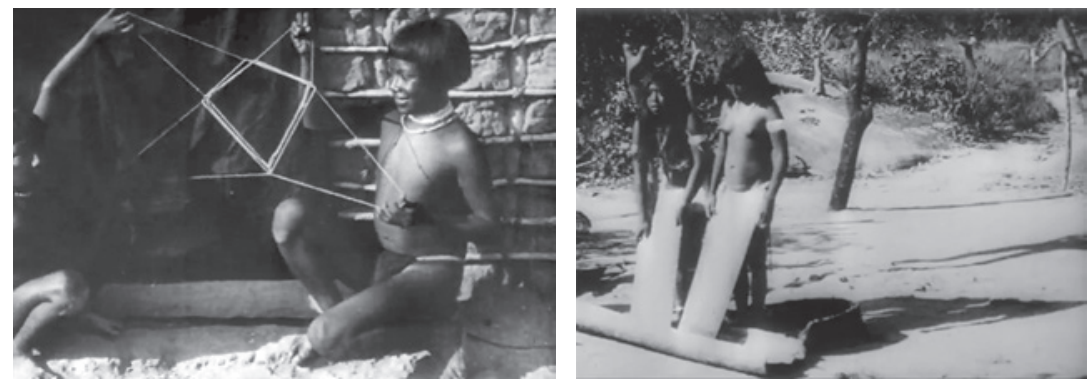

I.2 Though an excellent photographer, Theodor Koch-Grünberg had difficulty mastering the skills of cinematography. The shot of Taulipang boys making a string figure, left, is reasonable, but often his images are poorly framed as in the shot, right, of young Taulipang women grating manioc.

of the camera (figure I.2). He found the experience of shooting this material highly exasperating because the camera kept breaking down. It certainly did not convince him of the value of the moving image camera as a tool of field research. In total, he appears to have shot around 25 minutes of footage. Though much of this is lost or unviewable, a Io-minute compilation is available on the Web. ${ }^{16}$

But of all the early German-speaking ethnographic film-makers, the best known, and also the most controversial, is the Austrian anthropologist Rudolf Pöch, whose work was supported by both the Berlin Museum for Ethnology and the Imperial Academy of Sciences in Vienna. Just as Spencer had done, Pöch sought the advice of Haddon before taking a moving image camera, first to Papua New Guinea in I904-06 and then to southern Africa in I907-09. Less well-known is the film material that he shot in I9I5, during the First World War, when he was unable to travel abroad. This consists of a series of sequences of dances and traditional crafts performed by Russian soldiers from Central Asia detained in German or Austrian prisoner-of-war camps. Again, the volume of material involved is relatively small: less than Io minutes survives of Pöch's Melanesian footage, only 30 minutes of his southern Africa footage, and a mere $\mathrm{I} 3$ minutes of his prison-camp footage. ${ }^{17}$

Pöch is celebrated as a pioneer in many standard accounts of ethnographic film history. Although his film work is neither very accomplished nor extensive, it has become particularly well-known on account of a 56 -second film that he shot in 1908 in northern Bechuanaland (now Botswana). This showed Kubi, a San 'Bushman' of around 60 years of age telling a story into the horn of a phonograph about the antics of a herd of elephants at a nearby waterhole. In I984, Dietrich Schüller of the sound archive of the Austrian Academy of Sciences managed to synchronise these images with the audio recording that Pöch had simultaneously made on the phonograph. 

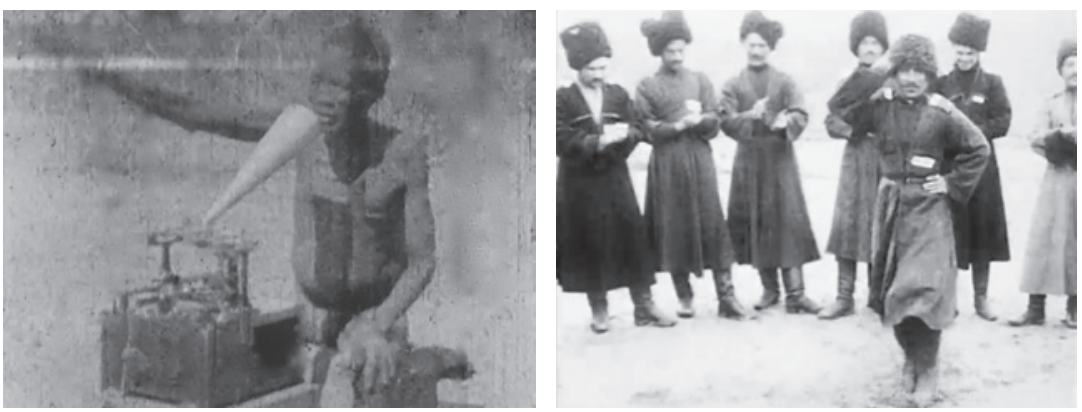

I.3 Films of Rudolf Pöch. Left, Kubi, a 6o-year-old San man, records a story about elephants at a nearby waterhole in August I908 at Camel Pan,

Ngamiland, in present-day Botswana. The phonograph recording was synchronised with the image in I984. Right, Russian soldiers, probably

Chechens, dance for Pöch's camera in a First World War prison camp.

The synchronisation is only approximate and was no doubt aided by the fact that for much of the film, Kubi's mouth is obscured by the phonograph horn. Nevertheless, despite the shortcomings of the synchronisation and the fact that it was achieved some seventy-five years after the original material was recorded, Buschmann Spricht in den Phonographen has been widely hailed as the first ethnographic film featuring synchronous sound. As a result, it is now available in multiple versions on the Web (figure I.3). ${ }^{18}$

In recent years, however, Pöch's reputation has darkened considerably. He held extreme raciological views, believing that culture was strongly determined by physiology. Although he died at a relatively young age in I92I, a decade before the rise of Adolf Hitler, his ideas were later warmly embraced by the National Socialists. Along with his substantial field collections of artefacts, photographs, sound recordings and films, Pöch had also collected human body parts in the hope of being able to prove his raciological theories. This reached a peak during his expedition to southern Africa, after which he shipped back to Vienna some 80 San skeletons, I50 skulls and even the corpses of a San couple preserved in a barrel of salt. All of this material had been acquired under the most ethically dubious, as well as illegal, circumstances. The increasingly intense criticism of this particular aspect of his activity since the turn of the present century has led to a more general denunciation of Pöch and all his works, while the southern African human remains have been the subject of a still ongoing process of repatriation. ${ }^{19}$

However, this ethnographic film-making activity by German-speaking anthropologists in the early years of the twentieth century, although precocious, was but a pale shadow of the production of films of ethnographic interest in France over this same period. In marked contrast to Germany, the most active producers of this kind of film in France at this time were 
not museums, but commercial production companies, whose operators were sending back films from all over the French colonial empire and beyond. But given the commercial nature of these films, I defer further consideration of them until Chapter 2.

Although publicly funded museums may not have been involved, another museum-like venture based in Paris was an active producer of short films of ethnographic interest at this time. This was Les Archives de la Planète, a private collection of films set up in I9I2 by Albert Kahn, a hugely wealthy investment banker. The extraordinarily ambitious aim of this collection was to document as comprehensively as possible, by means of both photography and film, all human customs across the globe. In part, this was a straightforward salvage project, but it was also oriented towards the future in the sense that Kahn held what now seems to be the most unworldly belief that by presenting these visual records to the elite figures whom he invited to his mansion on the eastern outskirts of Paris - intellectuals, leading politicians, religious authorities, military figures - it would be possible to promote international understanding and hence world peace. ${ }^{20}$

Under the direction of the distinguished Sorbonne geographer Jean Brunhes, professional camera operators were sent out by the Archives, ideally, though in practice rarely, accompanied by a geographer or other suitably qualified academic, to locations across the world. The customs that they were asked to document included not just the standard subjects of ethnographic film at this time (i.e. technical processes and ceremonies), but also the small, usually unconsidered details of everyday life, such as people walking in the street, a group of women washing clothes, a woman breastfeeding her baby.

The principal task of the Kahn operators was to take photographs, using the recently developed Lumière Autochrome colour process, and of these they took some 72,000 between I9I2 and I933 (when the project came to an end after Albert Kahn lost his fortune in the great stock market crash of I929). Over this same period, cameramen directly employed by Kahn also shot around 165 hours of silent black and white $35 \mathrm{~mm}$ footage. This was later supplemented by a further is hours of material purchased from newsreel agencies and other sources. Although the project was supposedly global in its reach, for obvious logistical reasons most of this footage was shot in Europe and North Africa, though there was also a significant quantity of material from the Middle East and Asia, particularly from Japan where Kahn had substantial financial interests. In total, the archive gathered together material from forty-eight different countries.

One of the most interesting and substantial bodies of material within the collection concerns the vodoun religious cults of Bénin in West Africa (then still known as Dahomey). This material - the only footage in the Kahn archive from sub-Saharan Africa - was shot over a six-month period 

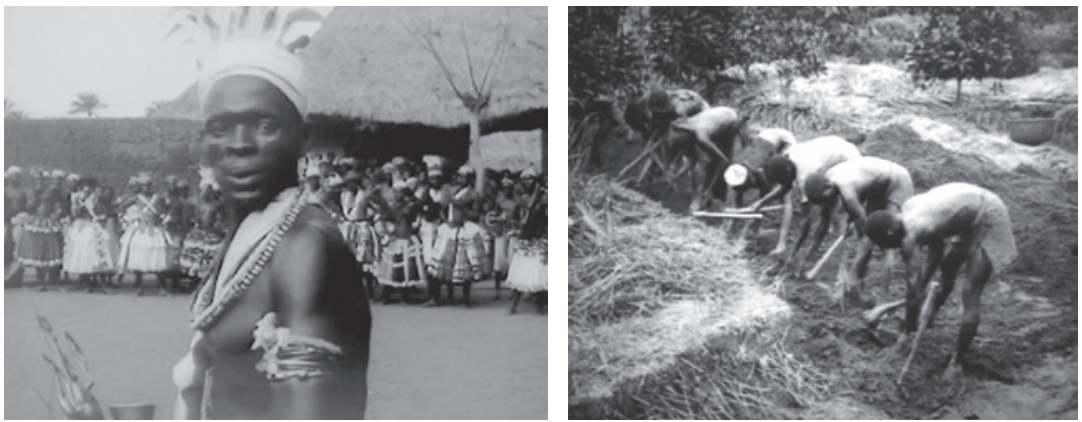

I.4 Aupiais-Gadmer footage from Dahomey (I930). Left, in a rare moment of reflexivity, the leader of the vodoun cult of Hèbiôssô, god of Thunder, dances up to the camera. Right, converts discover the moral virtues of labour in the Christian mission.

in I929-30 by Frédéric Gadmer, one of the most experienced cameramen employed by Kahn. In shooting this material, Gadmer worked under the direction of Père Francis Aupiais, a progressive Catholic missionary with some knowledge of academic anthropology. Aupiais had lived in Dahomey for over twenty years and was deeply committed to reconciling what he considered to be the highly moral quality of vodoun ceremonial life with the Christian message. Kahn had met Aupiais on one of the latter's visits to Paris and had offered to pay for Gadmer to work with him on the condition that the material that they produced concerning vodoun would be deposited in the Archives. As part of the deal, it was agreed that Gadmer would also shoot material on the work of Aupiais's mission in Dahomey, which the mission would then be able to edit and use for its own purposes. ${ }^{21}$

In total, Gadmer shot some six hours of footage in Dahomey, two-thirds of which were dedicated to matters relating to vodoun. To Aupiais's particular regret, however, no provision was made for recording sound. Moreover, as with the great majority of the footage in the Kahn archive, this material was intended to document the ceremonies in an objective fashion rather than provide the wherewithal from which later to cut a documentary, as that term would be understood today. Thus, although the images are almost invariably beautifully composed and executed, in general the material has been shot in accordance with the most uncompromising of documentation principles, that is, in long wide-angle or at most mid-shots from a tripod, with relatively few pans, or changes of framing or position, and mostly at a certain distance from the subjects (figure I.4).

Despite these limitations, today this footage represents an invaluable record of the practice of vodoun in its heyday, and since I996 the Musée Albert-Kahn, which is now the custodian of the Archives de la Planète 
collection, has been working with partners in Bénin to make it available to current generations of Beninois. However, at the time that it was made, this footage landed both the principal parties to the project in serious trouble. In Dahomey, Tôngôdô, a leading priest of the vodoun cult, and one of Aupiais's principal collaborators, was removed from office by his peers for having revealed too much. Meanwhile, in France, although the footage was received enthusiastically by Albert Kahn and the Parisian intellectuals to whom he showed it, including the eminent anthropologist, Lucien LévyBruhl, the senior figures of Aupiais's own missionary order felt that it gave far too positive an impression of vodoun and thereby undermined their work in Africa. Not only did they prohibit Aupiais from showing the material in public, but for many years, they did not even allow him to return to Dahomey.

A very different kind of film-making in sub-Saharan Africa that generated footage of ethnographic interest in the interwar years in France took the form of expedition films. These were often transcontinental or at least transregional in scope, and although they had a variety of sponsors, routes and objectives, underpinning most of them was an unabashed celebration of the French colonial project. The most well-known of these is La Croisière noire, released in 1926 to great acclaim: the première was even attended by the French President, Gaston Doumergue.This film followed eight Citröen half-track vehicles as they proceeded, over the course of eight months, from Colomb-Béchar, a colonial garrison town in Algeria, close to the Moroccan border, south across the Sahara to the Niger river basin, then east through the French colonies of Central Africa and the Belgian Congo, before arriving finally at Antananarivo, the capital of Madagascar, in July I925. In the final phase of the journey, the expedition divided into four groups at Kampala, one going north to seek out the source of the Nile, the others going south to Mombasa, Dar-es-Salaam and even the Cape, but all eventually reuniting in Madagascar.

Both the expedition and the film were paid for by the Citroën company, and at one level, La Croisière noire could be read as no more than a publicity stunt intended to promote Citroën half-track vehicles as a better means of crossing the difficult terrain of the Sahara and Central Africa than railways. But dedicated as it is in an opening title to 'The Young People of France' and supported logistically in various ways by French colonial authorities, this film can also be read as a resounding paën of praise to the 'civilising' French presence in the continent and a triumphalist reassertion of the country's imperial ambitions after the pyrrhic victory of the First World War. ${ }^{22}$

The director, Léon Poirier, and the cinematographer, Georges Specht, were both already distinguished figures in French cinema, and the technical quality of the film was remarkably high for the period: it also involved field sound recordings that were later incorporated into a soundtrack. Over the 

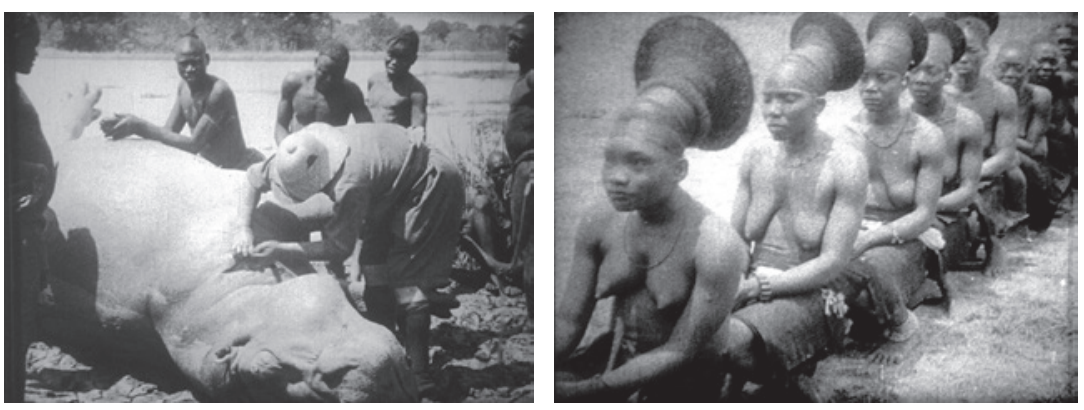

I.5 La Croisière noire (I926) combined big game hunting with ethnographic reportage, left. The hairstyles of Mangbetu women of the Belgian Congo, right, based on cranial elongation, had a major impact on fashionable coiffure in Paris.

course of the journey, Poirier and Specht filmed a number of interesting sequences of traditional custom, including dances, initiation ceremonies, the disturbing lip-plates of the Sara Kaba women in Chad and an open-air court case about a matter of stolen fish among the Wagenia of the thenBelgian Congo (now the Democratic Republic of Congo). A sequence about the practice of cranial deformation and the resulting remarkable coiffure of Mangbetu women gave rise to the abiding iconic image that appeared on publicity posters for the film and had a major impact on Parisian fashions (figure I.5). Many years later, Jean Rouch, while acknowledging the imperial tenor of the film, praised the directorial skill of Poirier, describing La Croisière noire as 'the first true film' to be made in sub-Saharan Africa. ${ }^{23}$

A very different and highly unusual example among French expedition films shot in Africa in the interwar years is Voyage au Congo. This was released in 1927 and was jointly directed by the well-known writer, André Gide and his sometime lover, Marc Allégret, who would later go on to become a distinguished film director in his own right. While Allégret shot and edited the material, Gide formulated the elegant literary intertitles (figure I.6). Despite the celebrity of the directors, this film remains curiously neglected in the literature of visual anthropology.

In marked contrast to most other French interwar expedition films in Africa, the reference to the journey itself and the French colonial presence is minimal: instead, Voyage au Congo proceeds via a series of vignettes of the cultural life of the peoples whom the film-makers meet as they travel through Central Africa, with, unusually for the period, a particular emphasis on the activities of women. It also includes a well-executed fictionalised sequence in the central part of the film which follows the courtship of a young Sara couple and the negotiation of bride-wealth payments. This 

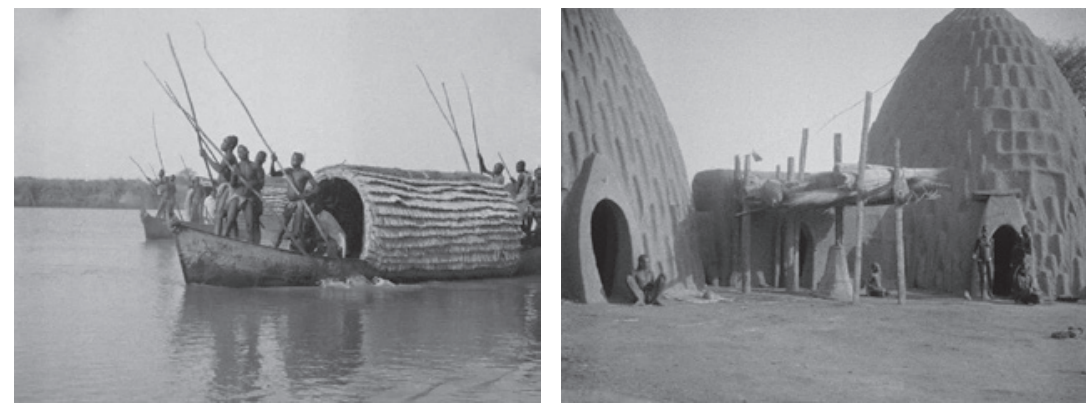

I.6 Voyage au Congo (I927). On the banks of the Logone river, French Equatorial Africa. Left, 'When the water is low, the pole is used to advantage over the paddle'. Right, a Massa village: 'The regular reliefs that decorate the houses form steps that allow one to forgo scaffolding during construction.'

sequence involves a sense of relaxed intimacy between film-makers and subjects that would not be achieved again in African ethnographic filmmaking until the works of Jean Rouch in the I950s. ${ }^{24}$

Yet although Voyage au Congo does not directly celebrate the French presence in Africa, in other senses it remained complicit with the colonial regime, in that it makes no reference to certain compromising circumstances that arose during the making of the film, which Gide and Allégret would later describe in print. These include the exploitation of Africans in the forest extractive industries run by private companies and also as forced labour working for the French colonial state. The latter even included working under duress as porters for Gide and Allégret themselves. Nor does the film allude to the sexual dalliances that Allégret sustained throughout the journey with a series of local prepubescent girls: these are described in his personal diary which was published only in I987, some fourteen years after his death. ${ }^{25}$

In addition to these transregional expedition films, the French also made a large number of films directly linked to particular colonies, at least some of which are of ethnographic interest. From the I920s, the French Colonial Ministry began to support the making of films that could be shown through established cinema distribution networks around France with a view to raising both awareness of and support for the French overseas empire. Some African colonies even had their own film-making programmes, Cameroon and Madagascar being particularly active in this regard. This activity intensified towards the end of the decade, as film-makers prepared for the International Colonial Exposition of I93I in Paris, where, over the course of six months, some 300 films on colonial subjects were screened in a cinema of I,500 seats. While most of these films concerned colonial modernising projects 
- roads, ports, forest industries, hospitals, campaigns against sleeping sickness and so on - a considerable number were exclusively or predominantly concerned with social and cultural aspects of indigenous life within particular colonies. $^{26}$

Most of these films provided little more than a descriptive inventory of architecture, subsistence practices, crafts and dances within a given geographical area. One significant exception was Sso: rite indigène des Etons et Manguisas, released in I935. This film concerns an elaborate male initiation ceremony involving two subgroups of the Beti in Cameroon. It is a substantial and well-made film of 56 minutes, featuring a musical soundtrack recorded on location, albeit asynchronously. It was directed by Maurice Bertaut, a senior colonial officer in Cameroon who had previously carried out a doctoral study of the customary law of another Beti subgroup, the Boulou. It was shot and recorded by René Bugniet, a professional cartographer who had also trained as a film-maker and who had made at least a dozen previous films for the Cameroon colonial administration.

Now no longer practised, the sso ceremony took its name from a particular species of small antelope admired for its speed through the forest. It required the initiands to undergo a series of physical ordeals over the course of six months, along with periods of seclusion and hunting in the forest, interspersed with ritual battles and dancing in the village plaza. A sso ceremony usually had a ritual sponsor, who would guarantee the considerable quantities of food and drink consumed. The sponsor could thereby expiate some past moral infraction while at the same time gaining great personal prestige. $^{27}$

Bertaut and Bugniet's film begins with an interesting fictionalised sequence in which, following the death of his son, a senior man, one Bilimá, attributing this loss to a fight that he had had with his brother, undertakes to expiate this infraction by sponsoring a sso ceremony. Thereafter the film follows the unfolding of the ceremony in a largely straightforward descriptive manner (figure I.7). This sso turns out to be an impressive affair, involving at one stage perhaps as many as eighty initiands, and featuring many remarkable ordeals and extraordinary dance performances.

Apart from a few occasional lapses, the voice-over, scripted and performed by Bertaut, is remarkably free - for the period - of colonialist or racist prejudice, while the shooting and sound recording by Bugniet is also generally of a high standard. Somewhat disappointingly, the film concludes with a particularly voyeuristic final shot, of the kind that also features in Bugniet's earlier work, in which he explores the scarified bodies of three young women 'to dispel any unpleasant memory of the ordeals undergone by the initiands'. But otherwise, Sso is perhaps the closest pre-war example of the kind of event-based ritual film that would become a staple of ethnographic film-making after the Second World War. ${ }^{28}$ 

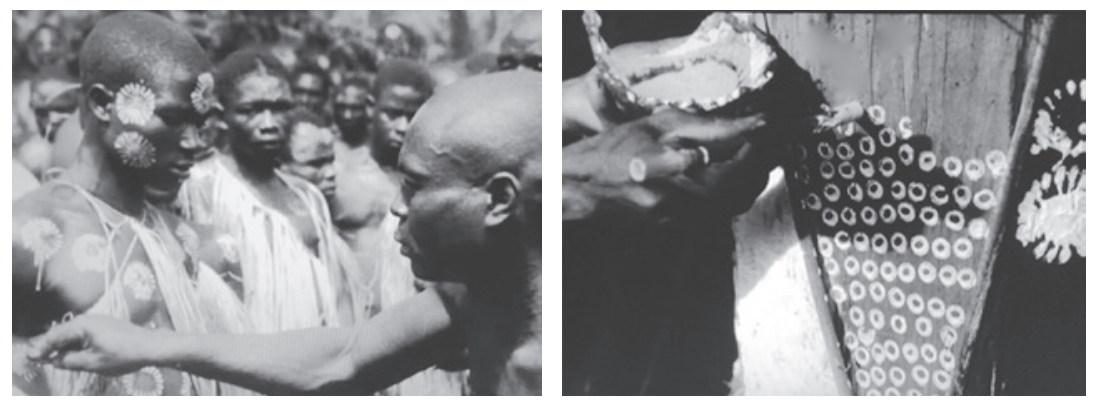

I.7 Scenes of Beti male initiation, Cameroon, as featured in Sso (I935). This film anticipates the event-based ritual films of the post-war period.

It was also in the mid-I93os that the first ethnographic films involving French anthropologists de métier were made, though there appears to have been only two cases. One of these is the case of Marcel Griaule, a founding figure of modern French anthropology and later the mentor of Jean Rouch. In I935, on his third expedition to Africa, which was to the territory of the Dogon of the Bandiagara Cliffs in what is today Mali and then was the French Soudan, Griaule took with him a young professional cameraman, Roger Mourlan. Initially, Griaule used the footage shot by Mourlan merely to support his lectures and his research, notably to work out the series of drawings of dance movements that are offered as a supplement to his classic work, Masques Dogons, published in I938. But in I940, Griaule collaborated with a professional film production company to produce two films from this footage, Au pays des Dogons and Sous les masques noirs, each of about ten minutes duration. These were made specifically to support an exhibition on French colonial Africa at the Musée de l'Homme in Paris. ${ }^{29}$

This exhibition was due to be opened by the Minister of the Colonies, Georges Mandel, and no doubt for this reason both films open with rolling titles offering a panegyric to the 'colonising genius of the French' and a complimentary allusion to Mandel himself. Whereas Au pays des Dogons offers a general overview of Dogon life, Sous les masques noirs focuses more specifically on masks, starting with their manufacture and then showing them in use during a funeral ceremony, though curiously, in this second film, the Dogon are not referred to by name. Instead, the commentary merely alludes to 'one of the most mysterious peoples of Black Africa'.

Both films were superbly shot by Mourlan and, taken together, offer a valuable ethnographic account of daily life among the Dogon as well as testifying to the extraordinary beauty of Dogon masks and the vitality of 

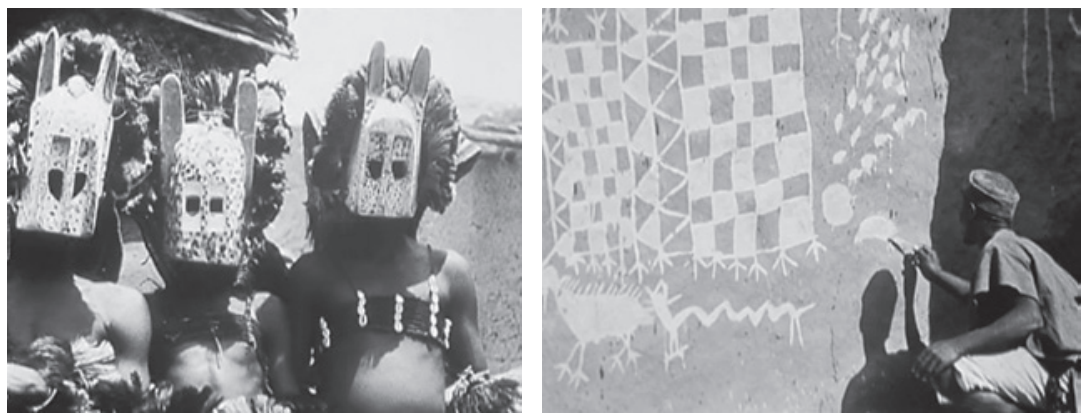

I.8 Marcel Griaule's films of the Dogon (shot in I935). Left, three boys pose in Hare masks; right, a mural ostensibly being painted in a totemic shrine, though in reality it was on the wall of the Griaule expedition bungalow.

their ceremonial performances. However, in common with Griaule's textual accounts of the Dogon, these films present the Dogon largely as if they were living in an atemporal vacuum, more or less unaffected by the French colonial presence. Early in the second film, Griaule himself appears with his leading Dogon informants who are presented anonymously, as if they had no personal history and no contact with the outside world. But these informants include Doussu Wologuem, who was not only a Muslim, but also a First World War veteran, a member of the Légion d'honneur and a holder of the Croix de guerre.

In a much-cited interview, Griaule once claimed that everything shown in these films was entirely authentic and that nothing had been set up since the Dogon themselves would never have allowed it. ${ }^{30}$ However, this was not true, in a number of different respects. The designs that are shown being painted on what is said to be the wall of a totemic shrine in $A u$ pays des Dogons were, in fact, being painted on the wall of one of the modern bungalows built to house the expedition (figure I.8). In Sous les masques noirs, there is a shot of a slit gong being played, ostensibly as part of the funeral ceremony, when in fact these instruments are never played on such occasions and the shot was taken on a completely different occasion at the request of one of Griaule's expeditionary colleagues, the ethnomusicologist André Schaeffner. But most significantly of all, the 'funeral' shown in these films was not an actual funeral, but merely a performance paid for by Griaule.

The commentary tracks of the two films were scripted by Griaule but performed by professional voice artists in the mannered style of the time. While praising certain aspects of traditional Dogon life, these commentaries are also punctuated by condescendingly ironic comment at the Dogon's 
expense. No sound had been recorded in the field, so both films feature a soundtrack of extra-diegetic European music that varies from light classical to jazzy. In both regards, Griaule's films now seem much more anachronistic than the film of the non-anthropologists Bertaut and Bugniet. It has been suggested that the condescending attitudes that are a feature of Griaule's commentary script can be put down to the exigencies of having to work with a professional production company. However, it has to be said that there is a certain continuity between the ironic attitudes expressed in these films and those found in Griaule's influential methodological handbook, Methode de l'ethnographie. ${ }^{31}$

Apart from Griaule, the only other academically trained French anthropologist to make a film before the Second World War was Père Patrick O'Reilly, a Catholic priest of Irish descent, who studied under Marcel Mauss at the Institut d'Ethnologie and graduated in 1932. Two years later, supported by Paul Rivet, Director of the Musée d'Ethnologie du Trocadéro, the predecessor institution to the Musée de l'Homme, O'Reilly received a grant to carry out field research on Bougainville, an island in the North Solomons, then part of Australian New Guinea (and today part of the independent republic of Papua New Guinea). It was also a place where the religious order to which O'Reilly belonged, the Marist Fathers, had a well-established missionary presence. $^{32}$

The principal objective of O'Reilly's expedition was to collect objects for the Trocadéro museum (of these, he eventually shipped back around 4,000 ) and at the same time to make a film showing those objects in use. For this purpose, he took with him a sophisticated professional camera, the Debrie Parvo, with a lightweight Bell \& Howell camera as a back-up. Initially, he also had a professional cameraman with him, one Pierre Berkenheim, but from O'Reilly's own account it would seem that he shot a large part of the material himself. If so, given that there is no evidence that he had had any prior training or experience as a cinematographer, the technical quality of the footage is astoundingly high.

The main film that came out of the expedition, Bongainville, running to 70 minutes, was silent and offered a general ethnographic account of life on the island. Not surprisingly, given O'Reilly's brief, the manufacture of objects plays an important part in the film. But there is also much more, including some very well executed sequences of fishing, which involves a remarkable system of nets suspended from towers built out to sea, and various ritual events, including a marriage, a funeral, and a male initiation ceremony (figure I.9). What is particularly notable about these images is the easy and intimate rapport that the film-maker had clearly developed with his subjects.

In commenting later on the making of the film, O'Reilly claimed that he treated the subjects with great respect, never asking them to put on or 

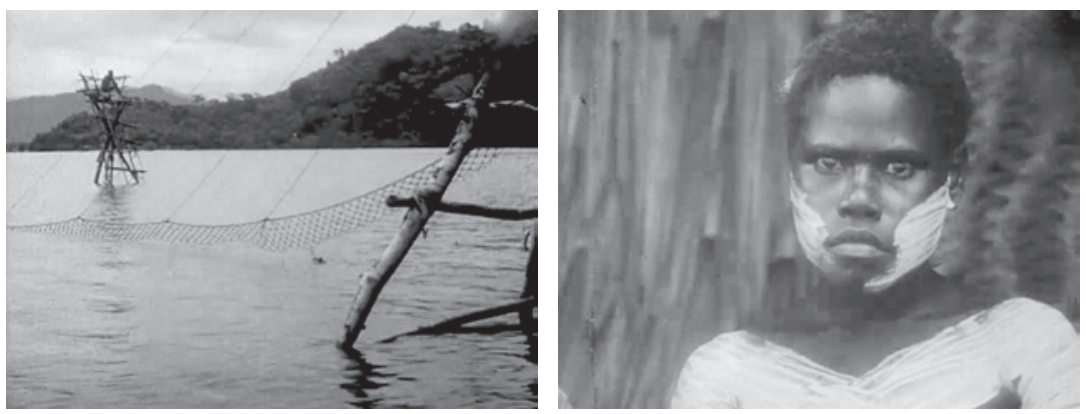

I.9 Bougainville (1935). Left, fishing is conducted by means of large nets slung from towers built out to sea. Right, a widow paints herself with white clay.

take off any items of clothing, nor asking them to remove any medallions (crucifixes are indeed visible from time to time) or add flowers to their hair (as the tropes of the then highly popular South Seas fiction films required). He also aimed not to intrude with his camera where it was not wanted, which is why only part of the initiation ceremony is shown. This is no doubt at least part of the reason why he was able to establish such a good rapport with the subjects.

However, as well as the main film, a shorter film of 20 minutes was cut from O'Reilly's material for general audiences and released under the egregious title, Popoko - île sauvage. O'Reilly had a very low opinion of this film, but consoled himself with the thought that it featured a soundtrack of two songs recorded on location. For many years, only one copy of the main film existed, but in the early I970s, encouraged by Jean Rouch, the French scientific research agency, Centre national de la recherche scientifique (CNRS), agreed to make a new copy. By then elderly, O'Reilly took the opportunity to shorten the film to 37 minutes and to add a voice-over commentary. This version can now be readily viewed through the CNRS online videotheque. ${ }^{33}$

In comparison with the ethnographic film legacy of the French colonial period, the filmic record that the British left behind of local indigenous social life and custom in their many colonies across the globe in the early twentieth century is extraordinarily meagre. When the British made films in their colonies, they tended to be propaganda films about their own modernising activities. Films that respond specifically and exclusively to the immense social and cultural richness of the South Asian subcontinent during the British Raj are very few while those concerned with local life and custom in the many British colonies in Africa during this period are even more limited in number. ${ }^{34}$ 

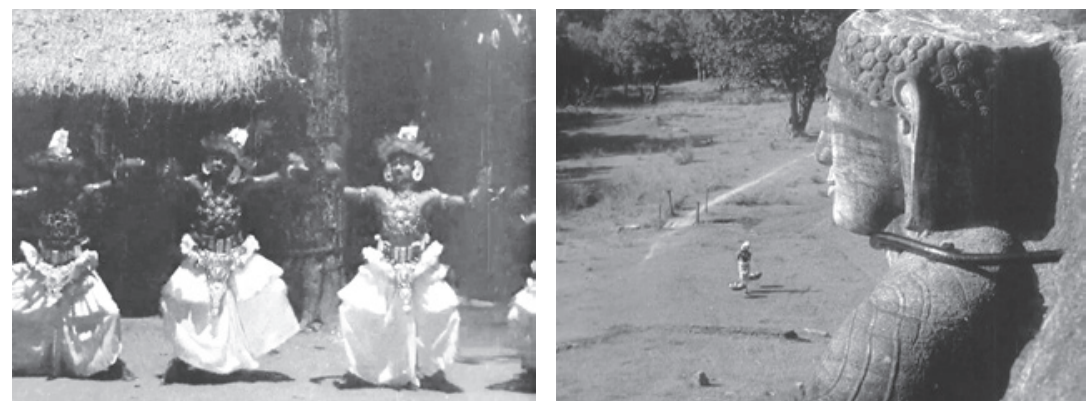

I. Io Song of Ceylon (I934). 'The Apparel of a God'. In the last sequence, magnificently costumed dancers are intercut with images of a giant statue of the Buddha, though the ethnographic validity of this association has been questioned.

In the context of this relative absence of films directly concerned with ethnographic subjects from the British colonial period, one film that stands out particularly is Basil Wright's celebrated documentary poem, The Song of Ceylon. This film might not be considered an ethnographic film in any conventional sense, but it certainly has ethnographic qualities. Originally commissioned by the Empire Marketing Board (EMB) as a four-part travelogue intended to promote the Ceylon Tea Marketing Board, in the course of post-production it became instead a poetic meditation on the religious texture of traditional life on what is now the island of Sri Lanka. It was released in I934, after the EMB had been dissolved, by the General Post Office (GPO) film unit which was headed by Basil Wright's mentor, John Grierson. ${ }^{35}$

The film is divided into four parts, presented as if they were movements in a symphonic composition. The first part follows Sinhalese pilgrims to the sacred mountain of Sri Pada (known to Europeans as Adam's Peak), while the second presents everyday subsistence activity on the island - fishing, pottery, house-building, rice cultivation - and shows children being trained as dancers. The calm and measured nature of this traditional way of life is then contrasted with the 'voices of commerce' in the third part. This consists of various scenes of colonial economic activity, including the harvesting of tea, the laborious processing of copra and the dispatch of goods on international freighters, overlain with clipped telephone voices referring to stock prices and logistics. The final part returns to religious themes, juxtaposing some magnificently costumed dancers with images of the giant statues of Buddha carved in granite at Gal Vihara (figure I.IO).

The film was mostly shot by Wright himself in a manner that he would later explain had been much influenced by the advice he received from 
Robert Flaherty when the latter was briefly attached to the film unit of the EMB in I93I. However, notwithstanding the excellence of the cinematography and the often-daring visual transitions, arguably the most impressive aspect of the film is the highly elaborate soundtrack entirely recorded at post-production in London. In developing this soundtrack, Wright was assisted by another important figure of early documentary film-making, Alberto Cavalcanti, the Franco-Brazilian film-maker who was then working with the GPO film unit. The avant-garde British composer Walter Leigh was also recruited to work on the soundtrack.

Inspired by the contrapuntal theories of the Soviet film-maker Sergei Eisenstein, this soundtrack combined a broad panoply of sounds, including Sinhalese music performed by musicians brought to London specifically for the purpose, Leigh's avant-garde musical compositions, a range of special effects and number of disembodied voices, some speaking English, others Sinhalese. In addition, it featured a series of texts offering ethnographic observations about Sinhalese life originally published by the sea captain Robert Knox in I68I and based on his knowledge of the island as derived from his twenty-three years of captivity there. This text was read in a most entrancing manner by Lionel Wendt, who was a Burgher (a person of mixed Dutch and Sinhalese descent) and by profession a photographer. Wendt had also worked with Basil Wright and his assistant, John Taylor, throughout their lengthy shoot of several months, advising them on all aspects of traditional Sinhalese life.

Although The Song of Ceylon is widely acclaimed as one of the finest works of documentary cinema of the interwar years, the film has also been criticised, among other things, for presenting an idealised Orientalist vision of Sinhalese life in the I930s, and for glossing over the exploitation of workers on the tea plantations and elsewhere. It has also been questioned on more specifically ethnographic grounds, including the implication that the dancers juxtaposed in the final section with the statue of the Buddha are engaged in a religious performance of some kind, when in reality they are secular performers with no specific connection to Buddhism, and who hire themselves out to provide entertainment at weddings. ${ }^{36}$

But whatever the validity or otherwise of these criticisms - and there are certainly counterarguments that might be made against them - The Song of Ceylon remains a work of incontestable ethnographicness. Not only was it based on extensive prior research and a relatively lengthy shoot, but it is also informed by Robert Knox's ethnographic insights based on even more extended first-hand experience. In more general terms, The Song of Ceylon seeks to use the poetic power of cinema to communicate a sense of everyday customary Sinhalese life in a direct and respectful manner. It is surely for this reason that the film would later become a source of inspiration for two of the most influential ethnographic film-makers 
of the second half of the twentieth century, Robert Gardner and David MacDougall. ${ }^{37}$

\section{ETHNOGRAPHIC FILM-MAKING IN EMERGENT SETTLER STATES: Australia, Brazil, the Soviet Union}

While museum- or state-sponsored ethnographic film-makers in Europe in the early twentieth century were seeking to document the cultural diversity of colonial empires around the globe, similar processes were going on within emergent European settler states in Australasia, the Americas and Asia.

In Australia, the most substantial body of film of ethnographic interest of this period was produced by the Board of Anthropological Research (BAR), formally part of the University of Adelaide, but also closely linked to the South Australian Museum. From the mid-I920s until the late I93os, when its activities were curtailed by the outbreak of war, the BAR supported a series of annual expeditions, first to the northern part of South Australia, then Central Australia and eventually into Western Australia. During the course of these expeditions, some ten hours of footage about the Aboriginal population was shot. ${ }^{38}$

As early as I930, some of this footage was shot in I6 mm, a film gauge that had been introduced by the Eastman Kodak film company only in I923 and which was still widely regarded as an amateur format, suitable only for home-movie purposes. It did, however, have the great advantage over $35 \mathrm{~mm}$ of being very much cheaper. By I935, BAR film-makers were shooting exclusively in $\mathrm{I} 6 \mathrm{~mm}$, with even a small proportion in colour. This material was edited into a series of films, which, although partly structured around the logistical travails and the scientific activities of the expeditionaries, particularly in their opening sequences, were primarily organised on a thematic basis. In this latter sense, they anticipate to some degree the Desert People films made by Ian Dunlop in Central Australia in the I96os (see Chapter 3).

Where they are very different is in relation to the intertitles. These are often rather jocose, indicating that these films were primarily intended for popular audiences. This is symptomatic of the fact that at this point in Australian history, there was widespread interest in accounts of Aboriginal life since these fed into an intense debate then going on about the place of Aboriginal people within the settler nation's sense of its own nationhood.

The approach to anthropological fieldwork underlying the BAR expeditions was in the pre-Malinowskian survey mould, already considered oldfashioned by most university-based academic anthropologists by this time. The expeditions typically lasted no more than three weeks and involved multidisciplinary teams of biological anthropologists and medical researchers 
as well was anthropologists interested in cultural or social phenomena. Once an expedition had arrived at its destination, scouts would be sent out to encourage local groups of Aborigines to approach the expedition camp with the offer of food, steel tools, tobacco and medical attention. All research was then carried out through interpreters. The intellectual agenda of the expeditions was similarly old-fashioned: the interest in filming locomotion, hand gestures and technical activities that is a recurrent feature of the films is strongly reminiscent of Regnault's film project carried out beside the Eiffel Tower in I895, described at the beginning of this chapter.

None of the cinematographers who shot the BAR footage had had formal professional training. In his day job, the most prominent cameraman, E. O. Stocker, was a Sydney businessman, while Norman Tindale, the principal anthropologist, who also shot a number of the films, had started his professional life as an entomologist. Henry Fry had briefly studied anthropology following medical studies at Oxford, but earned his living as a doctor in Adelaide. Charles Mountford, who was also a talented photographer, was entirely self-taught both as anthropologist and cinematographer, having first become interested in Aboriginal life while working as an electrical engineer at the post office in Darwin, in the north of Australia.

Nevertheless, the footage that these cinematographers produced is of a remarkably high standard for the period. In addition to the general stability of the image and the quality of the framing and camera positioning, the BAR film-makers also shot various slow-motion sequences of actions such as spear-throwing, digging and chopping, as a complement to their interest in locomotion. As well as being technically accomplished, the BAR filmmakers appear to have established an easy rapport with their subjects. Not only were they able to film both women and men engaged in the demanding and skilful business of daily subsistence in the Australian desert in the most intimate way, but they were also permitted to film many of the most secret and sacred Aboriginal objects, sites and ceremonies, seemingly without restraint. By the request of the descendants of those who appear in these films, the viewing of this secret-sacred material is now restricted.

Some of this material is unflinchingly intrusive, notably the footage relating to the circumcision and subincision processes that constitute an important part of some Aboriginal male initation ceremonies. If certain ethical questions are raised for present-day audiences about this initiation ceremony material, most would unambigously condemn the sequences of sexual activity that are reported to have originally formed the now entirely censored final part of the film corresponding to the 1932 expedition to $\mathrm{Mt}$ Liebig. But these more intrusive sequences represent only a relatively small part of the total body of material produced by the BAR expeditions. Taking this material as a whole, one can readily understand why Ian Dunlop should consider this work as being of the highest quality and sensitivity, revealing, 

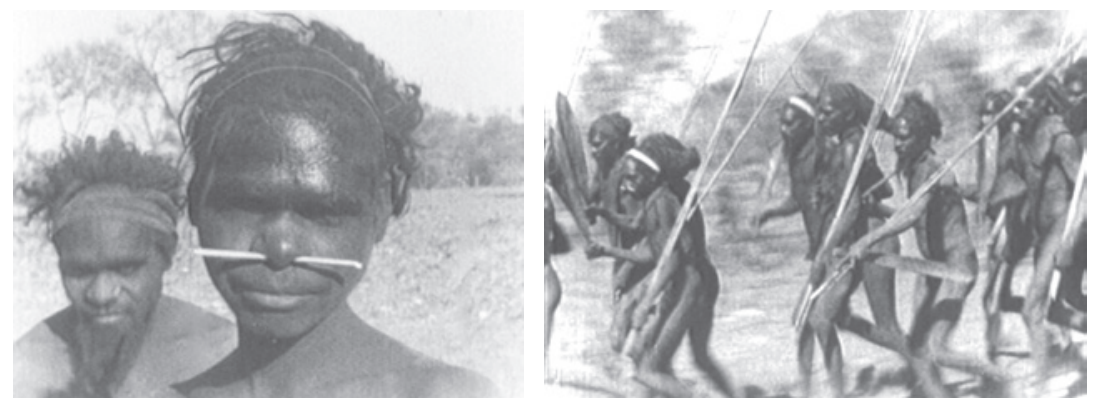

I. II South Australia Board of Anthropological Research films

(I920s-I930s). '... an extraordinary feeling of immediacy and veracity, the beauty and excitement of desert life'.

he suggests, 'an extraordinary feeling of immediacy and veracity, the beauty and excitement of desert life' (figure I.II). ${ }^{39}$

Another technically accomplished and particularly early example of ethnographic film-making in an emergent settler nation, but one that is relatively little known in the English-speaking world, is the work of Luiz Thomaz Reis, a junior officer in the Brazilian army and the official cinematographer of a programme to colonise the interior of the country that was rolled out over the first three decades of the twentieth century. Reis's most substantial ethnographic film, Rituais e Festas Borôro, released in I9I7, with a duration of 30 minutes, concerns the funeral ceremony of the Bororo of Central Brazil, later made famous by the writings of Claude Lévi-Strauss. $^{40}$

The merits of this film are both cinematographic and editorial. The coverage of the elaborate ceremony is impressively varied, involving a judicious mixture of wide and mid-shots. The camera is invariably well placed, allowing the dancers to move through the frame elegantly. The narrative structure of the film is of a kind that is easy to recognise a century later: in the first third of the film, the preparatory activities and certain leading figures who will participate in the ceremony are introduced, then, aided by frequent intertitles, the film simply follows the chronology of the event, culminating in a final burial sequence. A concluding intertitle suggests that this scene is reminiscent of the time before the arrival of Europeans in the New World (figure I.I2).

In terms of its technical and aesthetic quality, Rituais e Festas Borôro is undoubtedly one of the masterworks of early ethnographic cinema. However, from a strictly ethnographic point of view, the film is problematic in that it misrepresents the chronology of the Bororo ceremony in a radical fashion. In reality, now as much as then, the Bororo practice secondary burial: immediately after death, the body is buried in the centre of the village 

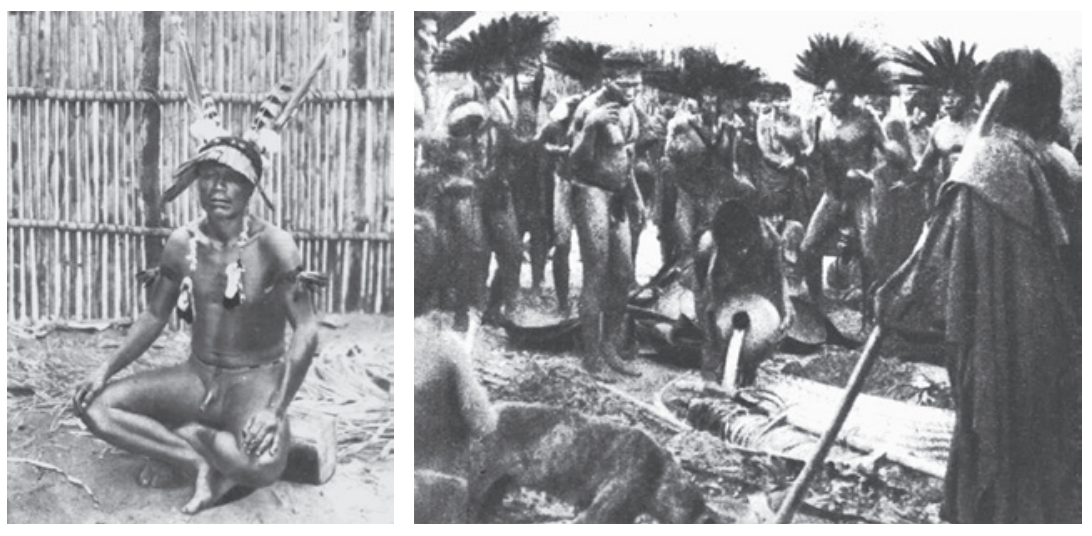

I.I2 Rituais e Festas Borôro (I9I7). Left, Buturaguire, aroetoráre, 'evoker of the spirits', photographed at the same time as the filming, though in the

film his lower body is excluded from shot; right, in the burial scene, placed at the end of the film contrary to ethnographic reality, the corpse is doused with water.

plaza and the ceremonial dancing begins. After about a month, by which time the flesh will normally have decomposed, aided by regular dousing of the grave with water - as shown in Reis's film - the body is exhumed and the skeleton is taken apart. The bones are then decorated with feathers and placed in a small basket before finally being immersed in a nearby lagoon.

Probably due to the propaganda purpose of the film, which was to suggest that Bororo culture could contribute to the formation of a new Brazilian national identity, Reis appears to have decided that there was a limit to the degree of ethnographic accuracy that it was advisable to inflict on his audiences. What is certain is that in editing the film, he reordered the chronology of his original material, placing the ceremonial dancing and the dousing of the grave before the first burial, whereas in reality they had come afterwards. The burial was then placed right at the end the film, as if it were the final, concluding event of the ceremony, in a manner that would have seem appropriate and familiar to the eventual non-indigenous audience. The more challenging scenes of exhumation and the secondary burial of the bones do not appear in the film at all.

But perhaps the most systematic use of film-making of an ethnographic character in connection with state-building in a settler nation in the interwar years was in the Soviet Union. Over a relatively brief and specific period, from the mid-I920s until the early I930s, many film studios in the Soviet Union were involved in the production of kulturfilms, a term borrowed from German to denote non-fiction films that had edifying educational, 
scientific or political messages to communicate. Although these films typically involved more editorial artifice than newsreels, and could even involve re-enactments by the subjects, they were generally not supposed to involve scripts, props or professional actors. Many of these films were of an ethnographic character in the sense that they concerned the customary life of one or more of the many ethnic minorities living within the boundaries of the Soviet political universe. ${ }^{41}$

The typical form of the kulturfilm is best understood in the context of Soviet nationality policy at the time. In the most summary terms, this was based, in principle, on respect for local cultural traditions and institutions (thereby supposedly distinguishing itself from the 'colonial' policies of the despised prior Tsarist regime), but at the same time on the assumption that these traditions and institutions would be progressively transformed so as to be compatible with membership of a modern, socialist supracultural polity, namely, the Soviet Union. In a typical kulturfilm, therefore, in the early part of the film, local cultural traditions would be presented in a broadly positive, often romantic light, but gradually, as the film unfolded, it would show how these traditions were being transformed for the better through contact with the agents of the Soviet state, resulting in a general improvement in the subjects' well-being.

A somewhat idiosyncratic example of the kulturfilm was A Sixth Part of the World, released in 1926. This was directed by Dziga Vertov, the PolishRussian director who would later make the highly acclaimed 'city symphony', Man with a Movie Camera, released in I929. The latter involved what Vertov himself called a 'ciné-race', that is, a rapid helter-skelter tour around a number of Soviet cities held together by a virtuoso array of editorial transitions and special effects, as well as a blizzard of carefully scripted intertitles. Although perhaps not quite as pyrotechnical, A Sixth Part of the World is much the same, though in this film, the 'ciné-race' covers the whole of the Soviet Union.

Commissioned with a very generous budget by Gostorg, the state export agency, and based on footage shot by a team of a dozen cameramen dispatched to all corners of the Soviet Union, including the shores of the Arctic, the Far East, Central Asia and the Caucasus, A Sixth Part of the World directly addresses the many ethnically diverse peoples within the Soviet Union. Repeatedly asserting their ownership of the Union, it urges them to contribute to collective prosperity by offering their products for export so that machinery that will transform their lives for the better - archetypically tractors - can be imported in exchange. At the same time, in conformity with the general pattern of kulturfilms, while signalling the richness of the cultural traditions spread over a vast area - the one sixth of the world referred to in the title - the film also celebrates, towards the end, the fact that some communities are abandoning or modifying their traditions so as to take advantage of the 
possibilities for prosperity, social justice and equality that are being made possible through their membership of the Soviet Union. ${ }^{42}$

While it is a remarkable film in many respects, the ethnographicness of A Sixth Part of the World is at best limited. Many individual shots within the film are both striking and ethnographically interesting, while the accumulation of images from across the Soviet Union communicates a strong sense of its cultural diversity. However, the combination of the adversarial, propagandistic nature of the narrative and the constructivist editorial strategy operates against sustained engagement with any particular social situation, event or group of people.

More conventionally ethnographic and also more typical of the kulturfilm format is Forest People, released in 1928 and directed by Alexander Litvinov, one of the most prolific Soviet non-fiction film-makers of the interwar period. Beautifully shot by Pavel Mershin, one of the leading Soviet cinematographers of the time, this film concerns a small community of Udege, a group of some I, 300 hunter-gatherers who live in the forests north of Vladivostok, on the extreme far east coast of Russia. In making this film and a companion expedition film, Through the Ussuri Area, Litvinov was advised by Vladimir Arsenev, a topographer, former military officer and self-trained ethnographer who had lived in the region for many years and had written a number of semi-fictionalised accounts of Udege life. ${ }^{43}$

Forest People employs a sophisticated and mostly realist film language to present a series of scenes of everyday life of the Udege. Among the most memorable scenes are a marriage negotiation, the total quarantining of a mother on her own during the period that she is giving birth, various shamanic performances and a remarkable sequence involving the hunting of a bear. But in some ways the most remarkable of all are the quiet scenes around the village, of mothers cradling their babies, men chatting and smoking their pipes, and children constructing their toys. No doubt based on the long-standing prior relationship developed by Arsenev with the Udege, Litvinov and his crew were clearly able to establish a close rapport with the subjects, which is reflected in their apparent ease in front of the camera. In his memoirs, Litvinov describes how he planned each scene together with the subjects, thereby avoiding the breaking of any cultural taboos and using re-enactment where necessary.

However, the last ten minutes of the 45-minute film have a more propagandistic purpose. After a sequence showing young people learning agricultural skills, a committee of Udege elders agrees to send a messenger, one Suntsai, to Vladivostok to request cattle, horses, a plough, even a school and a hospital from the government. In Vladivostok, Suntsai meets up with Arsenev who helps write out a formal request, which, of course, is duly granted. But before Suntsai returns home, Arsenev takes him to the cinema to see the other film that Litvinov made with the Udege, Through the Ussuri Area. 

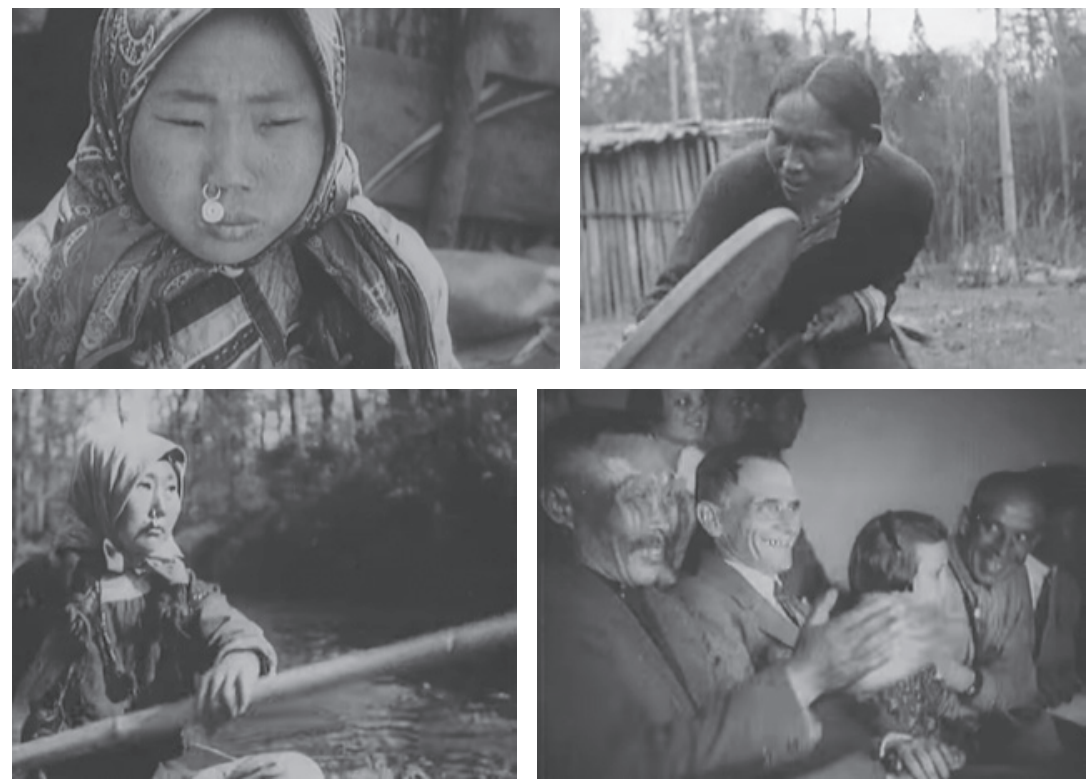

I.I3 Scenes from Forest People (I928). Above left, a bride listens to her family negotating the terms of her marriage; above right, a shaman calls upon the spirits to release animals for the hunters; below left, the hunter's wife goes to collect his kill; below right, 'Everything filmed truly!' - Suntsai, left, goes to the cinema with the ethnologist, Vladimir Arsenev.

Suntsai is delighted to see his own image on the screen and, according to Litvinov's memoirs, declared in broken Russian, 'Everything filmed truly!' (figure I.I3).

Litvinov's Udege films were released to international acclaim and he found himself being compared with Robert Flaherty, whose work was very popular in the Soviet Union at that time. Indeed it seems very likely that Litvinov himself had been directly influenced by Flaherty since a number of scenes in Forest People are distinctly reminiscent of Nanook of the North or at least of Flaherty's methods. As a result of this success, Litvinov was rewarded with generous budgets that enabled him to film a series of further kulturfilms, first on the Kamchatka Peninsula in 1929-30, then in the circumpolar regions of Chukotka in 1932-33, and then again in Kamchatka in 1934 .

However, from the early I930s onwards, the makers of kulturfilms as well as documentary film-makers more generally, came under fierce attack in the Soviet Union for making films that were not sufficiently 'ideological', that is, for not promoting socialist principles and celebrating the achievements of the Soviet state overtly enough. In response, whereas previously the 
benefits of contact with the Soviet state had typically been celebrated only towards the end of a kulturfilm, this theme began to take them over completely. Moreover, in order to ensure that this message was communicated to greatest effect, kulturfilm-makers began to bring in professional actors, who by definition were not from the community being represented. In the early I930s, the very term kulturfilm was abandoned and the potential of the form as a vehicle for film-making that was in any sense authentically ethnographic disappeared also.

All these developments can be discerned in the works that Alexander Litvinov produced in Kamchatka and Chukotka during the I930s. But by remaining 'on-message', Litvinov was able - unlike some of his kulturfilm colleagues - to survive the Stalinist purges of the mid-I93os and lived to become a strong supporter of local documentary production in Siberia in the post-war period. ${ }^{44}$

\section{ETHNOGRAPHIC FILM-MAKING IN THE USA PRIOR TO THE SECOND WORLD WAR}

As in other emergent settler nations, various projects in the USA in the early twentieth century were managed by museums and aimed at inventorising the lives of the original indigenous inhabitants of the country on film. In addition, both museums and academic anthropologists also made films of ethnographic interest abroad.

Even before the advent of the moving image camera, the villages of the Pueblo Indians and other native communities of the US Southwest had been a popular destination for large numbers of tourists, journalists, artists and photographers, all of whom were attracted by the beautiful traditional dress, pottery and architecture of these communities, but above all by their elaborate religious ceremonies. In the late I890s, moving image film-makers joined the throng. ${ }^{45}$

The Pueblo religious celebration that attracted the most outside attention was a ceremony often referred to at that time simply as the 'Snake Dance'. This was practised by the Hopi, then known as the 'Moki' (an outsider's term that modern Hopi reject). In fact, this dance constitutes merely the culminating phase of an extended ritual process which would be more accurately described as the Snake-Antelope ceremony since it involves both Antelope and Snake, two of the nine male secret societies traditionally maintained by the Hopi. Over the course of the ceremony, the two societies perform a series of complementary ritual roles. Traditionally, these ceremonies took place in August on a biennial basis but they were managed independently in the various Hopi villages, with some villages holding the ceremony on even years according to the Gregorian calendar, while in others it was held 
on odd years. In its fully elaborated form, the Snake-Antelope ceremony lasts for nine days and involves many different phases, as well as a complex series of cosmological and ontological ideas. Taken as a whole, it represents, as do many Hopi ceremonies, a prolonged petition to the ancestral spirits to grant generous rainfall and bountiful crops. ${ }^{46}$

The 'Snake Dance' that was of such interest to outsiders takes place on the ninth and final day of the ceremony. In the course of this dance, a collection of some fifty live snakes, previously gathered in the desert and then ritually cleansed, are briefly held in the mouths of members of the Snake Society as they dance in a circle before a line of members of the Antelope Society. The snakes are then symbolically fed with cornmeal before being returned to the desert so that they can carry the community's prayers for rain back to the ancestral spirits.

Most of the outsiders attending the Snake Dance in the I890s were not so much interested in the broader social and cultural context of the event as in the sensational sight of dancers in exotic costumes and bodypaint holding rattlesnakes in their mouths. Unsurprisingly, it was this image that the first film-makers sought to capture as well. As early as I898, the wellknown travel lecturer Burton Holmes sent his cameraman Oscar Depue to Orayvi Pueblo on First Mesa to capture 'a spectacle unique in its impressive savagery', as Holmes would later put it. Depue also returned the following year and shot the ceremony in the Walpi Pueblo, also on First Mesa. In I90I, Thomas Edison, the cinema pioneer, sent two of his leading cinematographers, James H.White and Frederick Blechynden, to Walpi where they shot four short films of different phases of the Snake Dance. In I904, the ceremony was filmed at Orayvi by the celebrated photographer Edward S. Curtis, who even claimed to have returned in 1906 to act as a priest. Some years after that, in I9I3, no less an eminence than the former President, Theodore Roosevelt and his sons were filmed watching the Snake Dance at Walpi. ${ }^{47}$

Museum-based ethnographers were also keen to document Pueblo ceremonial events, though they were more concerned about issues of authenticity. In I9I2, Pliny Goddard, a curator at the American Museum of Natural History (AMNH) in New York, commissioned the artist and cinematographer, Howard McCormick, to go to the Southwest and shoot some footage of the Snake-Antelope ceremony. However, in a letter to Goddard, McCormick reported that he was encountering only 'fake' performances for tourists. His difficulties were compounded by the fact that the ceremony typically takes place late in the day when lighting is poor. Even more problematic, he found that getting the community's permission to film was very difficult. ${ }^{48}$

However, McCormick did eventually manage to shoot an effective sequence of the Snake Dance and, moreover, from a privileged position, 
close to the ritual action. This was shot at the village of Supawlavi on Second Mesa and runs for around six minutes, a considerable duration for that time. Unfortunately, it appears to be the only part of McCormick's footage that has survived, so there is no indication that he filmed anything of the broader context of the Snake-Antelope ceremonies. It is also not clear whether what he filmed was a genuine religious celebration, though the fact that the audience in the background appears to consist primarily of indigenous children suggests that it was indeed an authentic enactment.

By the I920s, many Pueblo communities had become highly reluctant to allow their religious ceremonies to be filmed. This is made evident by another film about the Snake-Antelope ceremonies in the AMNH collection. In the catalogue, this film is dated to I925 and carries a descriptive title, but on the film itself there is no main title, nor any authorial attribution. Nor does it indicate in which Hopi village the footage was shot, though in fact it appears to be Musangnuvi on Second Mesa. The film runs for about 17 minutes and is clearly a fragment of a longer, more general film about the Hopi, since the first seven minutes shows a man carding wool before it abruptly passes on to the Snake-Antelope ceremony. ${ }^{49}$

What is especially interesting about this film - which is now subject to restricted access conditions - is that it contains some sequences of the phases of the Snake-Antelope ceremonies that occur prior to the Snake Dance. Also, through the intertitles, it offers some sense of the broader organisational context and meaning of the various elements of the ceremonies. However, in sharp contrast to McCormick's footage from Supawlavi, this material has all been filmed from a vantage point far from the ritual action, seemingly from the roof of a house overlooking the village plaza. Furthermore, as explained by an intertitle that appears just before the culminating moment when the Snake Dance is supposed to occur, 'due to the meddling of a Hopi from another village the consent of the snake priest was withdrawn and the last dance was not secured'. Instead, the film concludes with the material shot by McCormick in Supawlavi in I9I2.

A similar situation appears to have arisen during the production of another film made for the AMNH around the same period, this time about the shálako ceremony performed at the Zuni Pueblo. This film was shot by Owen Cattell in I923, the same year in which he also shot Land of the Zuñi and Community Work for the Museum of the American Indian (MAI). This latter film was directed by the eminent ethnologist Frederick W. Hodge, then the assistant director of the MAI, and covers a broad range of topics, including crafts, food processing and daily life, as well as various summer ceremonial sequences. ${ }^{50}$ By contrast, Shalako Ceremonial at Zuni, New Mexico, which was made at the request of the head of the AMNH Anthropology Department, Clark Wissler, is exclusively concerned with the shálako ceremony 
and does not appear to have been directed by Hodge, though he does seem to have played an important part in arranging for the film to be made.

The shálako ceremony, which takes place shortly before the winter solstice, constitutes the climax of the complex ritual calendar of the Zuni. The final phase of the ceremony is initiated by the appearance at dusk, on the occasion of a new moon, of six large masked figures, the eponymous shálako. These figures are conical, about $3 \mathrm{~m}$ high and I $\mathrm{m}$ across the base, with sides clothed in Hopi blankets (acquired through trade) and surmounted by masks featuring a diadem of eagle feathers, a turquoise horn on each side, and a mobile jaw operated from inside the figure. ${ }^{51}$

These figures are said to be kokko, ancestral beings who have returned to celebrate with their living descendants. The same term is used of the two men who take it in turns - on account of the weight - to inhabit and operate the shálako, a role for which they have had to prepare throughout the previous year through various forms of abstinence - dietary, sexual and occupational. The shálako are welcomed into the village with dance and song by two other, very contrasting masked groups, also representing spirit beings: the finely attired sayatasha, a group of five figures often collectively referred to as 'the council of deities' in the ethnographic literature, and the grotesquely costumed koyemshi, clownish trickster figures, of whom there are typically around ten. The role of the latter is both to entertain onlookers and to orchestrate the event itself. Although the shálako leave the village after twenty-four hours, the celebration continues for another four nights culminating in the ritual welcoming of ten young girls, the Corn Maidens, into the village plaza.

In Shalako Ceremonial, Cattell makes an attempt to follow the various stages of the ceremony, providing contextualising explanations in the form of extensive intertitles. But such is the complexity of the event that even the most experienced film-maker working under ideal conditions would have found it a great challenge to make a readily comprehensible film about the shálako ceremony. While Cattell was evidently competent in a technical sense, his repertoire as a cinematographer was seemingly quite limited. More importantly, conditions were far from ideal in that it is very obvious from the film itself that his presence was, at best, accepted with reluctance by the subjects.

Contrary to the assumption of some later commentators on the film, Cattell had been given formal permission to film by leading Zuni authorities, including the village governor Latario Luna, as well as the eminent priest Komosana. Their reason for granting this permission was that they had been persuaded by Hodge that a film about the ceremony would demonstrate its genuinely religious character and would thereby help to convince the government not to suppress Pueblo dances on the grounds that this suppression would be in violation of the constitutional protection of religious 

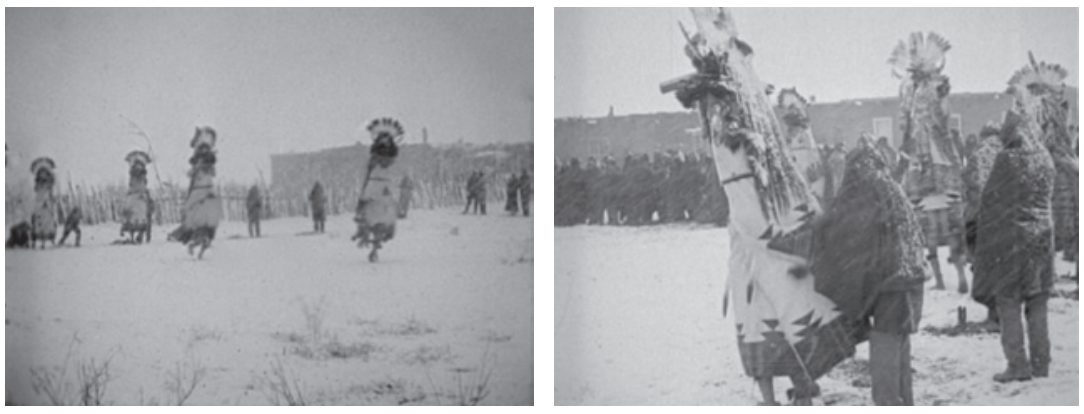

I.I4 Shalako Ceremonial at Zuni (I923). Ancestral beings, kokko, make their appearance at the shalako ceremony. Owen Cattell was permitted to film this ceremony to demonstrate its religious nature and thereby to support the Zuni's right to practise it under the terms of the US Constitution.

freedom. Luna and Komosana therefore agreed to let Cattell film provided that he maintained a respectful distance. Cattell clearly complied with this condition, since his camera is mostly situated far from the ritual action, so far indeed that it is often difficult for the viewer to see what is happening. But notwithstanding Cattell's discretion, some Zuni appear to have found the mere presence of the camera offensive. ${ }^{52}$

When the shálako masks finally do appear on the plain beside the village, about two-thirds of the way through the 29-minute film, Cattell's camera is situated at least I50 metres away. Indeed, one of the six masks does not appear at all because, as explained in an intertitle, its wearer did not wish to be photographed. Later, we are afforded a slightly closer view of the masks and it is indeed a truly magnificent sight to watch them as they run back and forth in pairs, in clouds of swirling snow (figure I. I4). But mostly the camera remains remote: the shots of the other two groups of masked dancers, the sayatasha and the koyemshi, are never more than oblique and distant, while the Corn Maidens are not seen at all for, as another intertitle explains, permission to film on the final day was withdrawn.

This intertitle states that 'the local representative of the Indian Bureau' was responsible for this withdrawal, though in fact the official in question, one Robert Bauman, had been urged to impose the ban by a political faction within the Zuni Pueblo opposed to the governor. This faction claimed that in giving permission for the film, Luna had violated the trust of the community and should therefore be removed from office. As a result of the ban, the forlorn final image of the film consists of a shot taken from some distance outside the village. This shows the backs of spectators standing on the roofs of the village, looking down into the invisible plaza beyond, where, one presumes, the Corn Maidens are making their entrance. 
Shalako Ceremonial raises a number of important questions about the power relationships implicit in any ethnographic film-making situation, as well as about control over the subsequent circulation of any culturally sensitive images that such situations might produce. These issues have recently been addressed by A:shiwi A:wan Museum and Heritage Center (AAMHC), a non-profit organisation set up in 1992 by a group of Zuni tribal members. Although this group does not appear to be generally hostile to ethnographic film-making by outsiders, in that they publicise Cattell's other films about the Zuni on their website, they take the view that Shalako Ceremonial should never have been made, since it shows certain situations that normally only initiated Zuni men would be allowed to see. ${ }^{53}$

However, the AAMHC also recognises that although the viewing of the film at the AMNH itself is now restricted, digitised copies of the film are already circulating widely beyond their control. Rather than take on the pragmatically impossible task of preventing this circulation, they therefore opted instead to work with the AMNH to produce a new version of the film. This is entitled The Shalako Film Revisited and excludes a sequence that should be seen only by initiated Zuni men: this is replaced by an intertitle explaining the reason for this exclusion. At the same time, certain factual and interpretative inaccuracies in the original intertitles were corrected, though the latter were retained to demonstrate the difference between the outsider and insider interpretations. A Zuni voice-over commentary that is much more detailed than the intertitles was also added. This version of the film has subsequently been used to promote cultural awareness among young people in Zuni by providing them with a visual dimension to support the oral accounts of the past that still actively circulate within the community. In order to control the circulation of the new film, the AAMHC has made it a condition of viewing it that there should always be a Zuni presence. $^{54}$

In addition to these film-making projects with Native Indian communities within the USA in the interwar years, the AMNH also supported a large number of expeditions across the globe that generated film footage of some ethnographic interest. These expeditions were often paid for by wealthy private sponsors, and the nature of the AMNH involvement was variable: sometimes its own personnel were directly involved, on other occasions it merely lent its name. The aims of these expeditions also varied: most focused primarily on geographical or zoological matters, only shooting ethnographic material along the way, so to speak, though a few were more directly concerned to engage with local people. Professional cinematographers were often involved, so the technical quality of the footage could therefore be high. However, even in the best cases, the ethnographicness of this material is limited by the fact that the film-makers had little knowledge of the people whom they were filming and rarely remained in one place long 
enough to establish any kind of rapport, let alone learn anything of the local language.

Much the same applies to the expedition films with which other US academic institutions were associated during the interwar years. One that has attracted some attention was Explorations in the Amazons Basin, released in I930. This was made in $1924-25$ in the course of an expedition to discover the source of the Orinoco via the Rio Branco in northern Brazil. The expedition was led and largely paid for by a wealthy amateur geographer, Hamilton Rice, who was associated with the University of Harvard while the film was shot by the celebrated pioneer of Brazilian documentary film-making, Silvino Santos. Although this film is certainly accomplished in a general technical sense, the superficiality of the sequences about the indigenous peoples of the Rio Branco is compounded by the blatant racism inherent in Rice's voice-over commentary. ${ }^{55}$

Less accomplished cinematographically, but somewhat more valuable ethnographically is the footage shot for the joint US-Dutch expedition to western New Guinea of I926-27, led by the anthropologist Matthew Stirling and associated with the Smithsonian Institution. Some of this material was edited into a film, later destroyed in a flood, that was entitled By Aeroplane to Pygmyland, and which Stirling used to support a series of lecture tours after returning from the expedition. But judging by the surviving footage, most of this material was shot at a great distance from the indigenous subjects and does no more than show them trading with the expeditionaries or just hanging about the expedition camp. It has a certain ethnographic value nevertheless, particularly when accompanied by the voice-over commentary recorded by Stirling in the I960s. ${ }^{56}$

Some of the best footage, both ethnographically and cinematographically, to arise from an expedition associated with a US museum in the interwar years, is the material shot by the Oscar-winning cinematographer Floyd D. Crosby and his assistant Arthur P. Rossi during an expedition to the Matto Grosso of Central Brazil in I930-3I, which was associated with the University of Pennsylvania Museum. This includes some interesting footage of the Bororo and of the Xinguano indigenous group, the Yawalpiti. In what could well be the first example of its kind in ethnographic film history, a few shots in the Bororo footage are in lip-synchronous sound recorded in the field on a then-new system provided by the main financial sponsor of the expedition, the RCA Victor phonogram company (figure I.I5, left).

In Matto Grosso, the Great Brazilian Wilderness, the principal film to arise from the expedition, which was released in I932, this footage was mostly used in a knowingly false and confused manner, though almost despite itself it still contains some material of genuine ethnographic interest (figure I.I5, right). Almost ten years later, the Pennsylvania Museum anthropologist on the expedition, Vincenzo Petrullo, arranged for some of the footage to be 

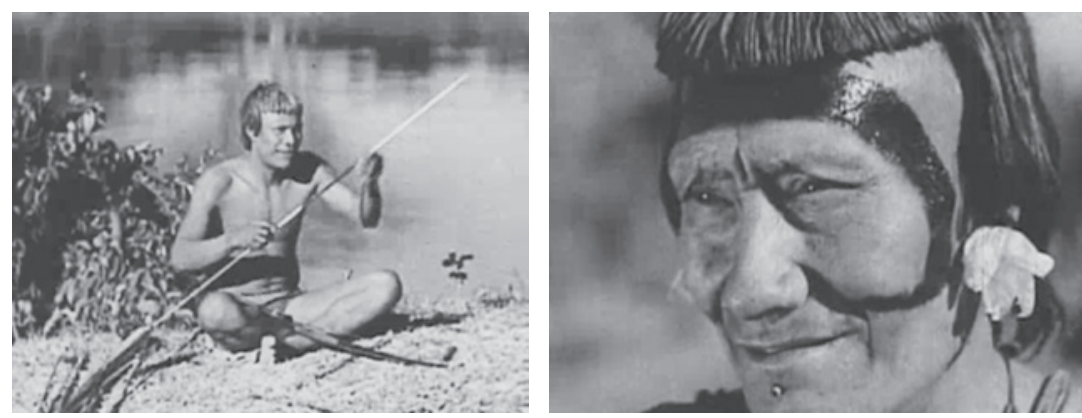

I. 5 Films from the Mato Grosso expedition of I930-3I. Left, in a supplementary film, a Bororo man explains how to make an arrow, probably the first example of on-location lip-synchronous sound recording in ethnographic film history; right, in the main film, Matto Grosso, the Great Brazilian Wilderness, a face in the crowd was identified in 2OII as that of Tiriacu Areguiri Ópogoda, a renowned Bororo shaman.

re-cut into two short films that are much more valuable from an ethnographic point of view. Along with some equally interesting out-takes from the main film, these two shorter films are now available on the Penn Museum website. ${ }^{57}$

While the number of ethnographic films produced by museum-based US anthropologists prior to the Second World War was hardly substantial, it was still greater than the number produced by anthropologists based in US university departments. Moreover, whereas film-makers associated with museums were at least motivated by a concern to produce edited films that they could then project for visitors to their institutions, university-based scholars tended to think that the primary reason for taking a camera to the field was simply as a means to gather visual data for later analysis. They normally did not set out with any prior intention to shoot material for a film that would be structured by an expository narrative.

One of the first US university-based anthropologists to use film in the course a field research project was none other than Franz Boas, widely regarded as the principal foundational figure of US anthropology and particularly well-known for his work over forty years with the Kwakwaka an indigenous group living on the northeastern shore of Vancouver Island and adjacent stretches of the Pacific Coast of Canada. In the winter of I930, at the age of 70 , Boas decided to try his hand at film-making in the course of what would prove to be his final field-trip to the Kwakwaka ${ }^{\prime}$ wakw. ${ }^{58}$

Boas took a simple moving image camera and a wax-cylinder phonograph to record sound. Technologically, this represented more or less the same array of equipment that Haddon had taken with him to Mer Island more than three decades before. Conceptually, Boas's project was also much the same as that of Haddon and indeed had certain resonances with the even 
earlier work of Regnault, as described at the beginning of this chapter. Based at Fort Rupert (known as Tsaxis in Kwagulth, the dialect of the local subgroup of Kwakwaka'wakw), Boas recorded around 45 minutes of material on a range of topics including ceremonial dance, music, chiefly competitive oratory, shamanic activities, games and some craft processes. His purpose was to to make a visual record that could be used later, in conjunction with the phonograph recordings, to explore the relationship between 'motor behavior' (i.e. bodily movement), and culture among the Kwakwaka $\underline{a}$ 'wakw. ${ }^{59}$

As in the case of Regnault and Haddon, the performances that Boas filmed were 'on-request performances', that is, they were put on, not in the normal social or ceremonial contexts of the activities concerned, but rather at his request in totally controlled and artificial situations where there was adequate natural lighting for the camera. Some of these performances were filmed in the yard of a European-style house while others were filmed in more open countryside, sometimes with an iconic totem pole in the background, at other times in front of a sort of palisade. The performers, mostly in ones and twos, are dressed in a mixture of traditional and modern dress.

Technically speaking, the footage is very poor, featuring numerous jump cuts and inadequate exposures - unsurprisingly, since Boas appears to have had no training whatsoever in the use of a moving image camera prior to this field-trip. In the end, it seems that Boas never completed the study for which he shot this material, in part because he believed (erroneously) that the wax cylinders had been stolen and in part because of his advancing years. It is dubious, in any case, whether his recordings would have been sufficiently sophisticated from a technical point of view to establish the correlations that he was seeking.

Owing to his great eminence in North American anthropology, Boas's efforts at film-making have attracted considerable attention, despite his evident lack of competence. However, there were a number of other US anthropologists of the interwar period who were also prepared to confront the technical and budgetary hurdles involved in film-making, but whose work is not so well known. One of these was Boas's own student, Melville J. Herskovits, most remembered for his work on the African cultural legacy among the African diaspora in the Americas.

Between I928 and I934, Herskovits shot almost three hours of footage in the course of three different field expeditions to Surinam, West Africa and Haiti. All these films are in black and white, and shot on $35 \mathrm{~mm}$ film, using an Eyemo, a compact, spring-wound camera produced by Bell and Howell specifically for newsreel cinematography. In addition, Herskovits also made over a thousand audio recordings of music and song on wax cylinder recorders, though this material was not synchronous with the film footage. ${ }^{60}$

Herskovits shared his mentor's interest in exploring the connection between motor behaviour and culture, and this is reflected in the nature 
of the material that he chose to shoot. In addition to the many sequences of music and dance, there are a considerable number of sequences on craft activities, as well as on subsistence activities, including collective work parties, since he was particularly interested in the possible continuities between motor behaviour in everyday life and the movements encountered in dance within the same society.

Herskovits's film work represents a considerable advance on that of Boas, not only in terms of sheer volume, but also editorially, in that both the variety and complexity of the subject matter are much greater. Although some 'on-request performances' are still included in the material, there are also many sequences of spontaneous behaviour, both in ceremonial contexts and in the form of everyday activities, particularly in the West African and Haitian material. Moreover, in contrast to Boas, Herskovits clearly thought of his material as being more than just research footage, particularly that shot in West Africa, since he later edited this into an informational film structured around a series of intertitles and maps presenting the various different groups of the region that he visited. This appears to have been intended to support his textual publications about these groups.

Yet although Herskovits's film work may represent a considerable advance on the work of Boas in an editorial sense, it has to be said that it remains highly deficient technically. The image is often unstable or underexposed, the positioning of the camera is often poor, and very few processes, technical or performative, are covered in their entirety from beginning to end. It is clear that he did not shoot the material with any sense of later editorial requirements since there is very little variety in the nature of the shots: the great majority of the material is shot in mid-distance wide-angle shots, with very few close-ups of either people or objects.

It has been suggested that Herskovits may have chosen to shoot in this detached, wide-angle manner believing that in this form, his material would provide more objective evidence in support of his arguments about the relationships between motor behaviour and culture. But if so, this merely confirms the fact that his approach still lay firmly within the classical paradigm of documentation film-making, even if, after the fact, he sought at the editorial stage to structure his material about West Africa into an expository pedagogical documentary.

Another of Boas's students to make films in the interwar years, and one whose work is much better known, was Margaret Mead. These films were made in the course of the field research carried out on Bali and in the Sepik region of Papua New Guinea in conjunction with her then husband, Gregory Bateson (who, as it happened, was a former student of Haddon at Cambridge). Over a three-year period, I936-39, with Bateson doing all the shooting but with Mead apparently playing the lead directorial role, 
they produced some twenty-four hours of black-and-white footage, two-thirds of it on Bali, one-third in the Sepik region. Although relatively modest by present-day standards, this was an unprecedented quantity of material, representing substantially more than the three hours produced by Herskovits, and completely dwarfing the quantities shot by academic film-makers of the generation of Haddon and Spencer. ${ }^{61}$

Another difference was that whereas Herskovits was still shooting on $35 \mathrm{~mm}$, Bateson shot on I6 mm: as Mead and Bateson intended from the start to shoot a large amount of film, they were obliged to keep their costs to a minimum. The camera that Bateson used was a Zeiss-Ikon Movikon, a model that would later be much favoured by German combat cinematographers during the Second World War. In addition to this film footage, Bateson also took a large number of photographs, only a small fraction of which have ever been published.

Mead and Bateson's primary concern was to record mother-child interactions since they believed that it was in this relationship that they would discover the key to understanding the development of schizophrenia, which was the main goal of their research. Their aim was to use the cameras, both moving image and still, as scientific data-gathering devices, in as objective a manner as possible. In one of their later publications, Bateson was careful to distinguish their way of working from the making of 'documentaries', though in the following passage, it is important to note that he is referring not to 'documentaries' as this term would be understood today, but rather to films such as Nanook of the North, which while purporting to be about real life were actually based on dramatised performances:

We tried to use the still and the moving-picture cameras to get a record of Balinese behavior, and this is a very different matter from the preparation of 'documentary' film or photographs. We tried to shoot what happened normally and spontaneously, rather than to decide upon norms and then get the Balinese to go through these behaviors in suitable lighting. We treated the cameras in the field as recording instruments, not as devices for illustrating our theses. ${ }^{62}$

By the I930s, camera technology had moved on sufficiently for film-makers to be able to aspire to film their subjects without the latter being aware that they were doing so. Indeed, in an attempt to maximise the objectivity of his footage, Bateson would sometimes use a right-angle lens so that the subjects would not realise that they were being filmed. However, at other other times, Mead and he would do the opposite, intentionally provoking reactions, with Mead appearing in shot offering a child a ball, a doll or a piece of cake to see how they would respond. When looking at this material today, one has the impression that one is watching some kind of open-air experiment in developmental psychology (figure I.I6, left). 

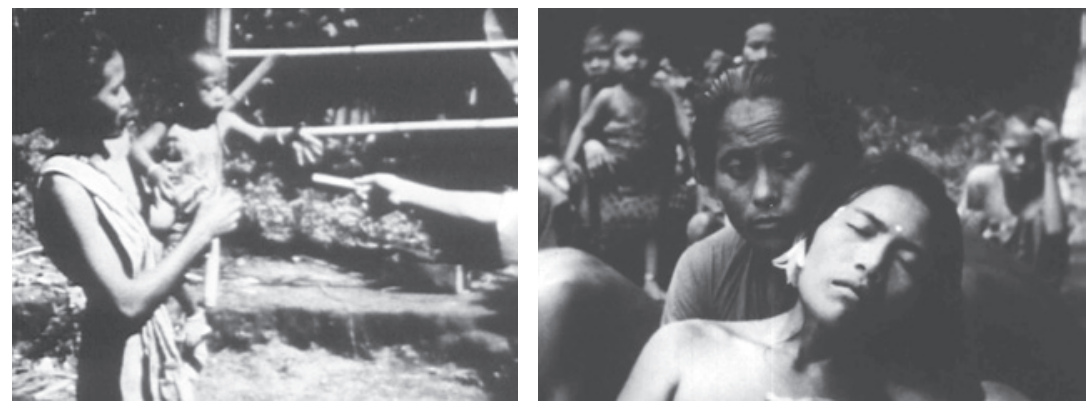

I. I6 Contrasting aesthetics in the films of Margaret Mead and Gregory Bateson. Left, a child is offered a piece of cake in Karba's First Years (I952); right, recovering from deep trance in Trance and Dance in Bali (I952).

Rather different from the main body of the footage was the material that Mead and Bateson produced with the assistance of their friend, Jane Belo, a North American artist and self-trained anthropologist who was then living on Bali. This footage concerned the tjalonarang, a theatrical play supported by a gamelan orchestra that was performed in the grounds of a temple. This was of particular interest to Mead and Bateson since they believed that it represented the playing out in public of certain crucial features of Balinese mother-child relationships. The narrative of the play turns upon the conflict between Rangda, a terrifying masked female witch, and Barong, a male dragon. It culminates in a scene in which Barong sends a group of his followers, armed with long daggers, to attack Rangda, only for her to repulse her assailants by the sheer power of her personal magic so that they fall to the ground in a deep trance. For Mead and Bateson, this scene represented a metaphorical re-enactment of the daily rejection by Balinese mothers of the emotional climaxes of their children, which, they believed, resulted in the sort of unresponsive personality that, in their view, characterised both the Balinese and schizophrenics in Western society. ${ }^{63}$

Although both Mead and Bateson used some of the rushes to support their teaching in the years immediately following their return to the USA, it was not until the early I950s that the editing of the material into a series of films began. By this time, Mead and Bateson had gone their separate ways both professionally and personally, so Mead oversaw the editing alone, though in the credits the films are attributed to both of them, with Bateson's name first in deference to alphabetical order. With the aid of the editor Josef Bohmer, Mead initially cut six films from the rushes, all of them relatively short, between IO and 2 I minutes long. These six films were presented as a series under the collective title, 'Character Formation in Different Cultures'. Two of the films are comparative, one of them, Childhood Rivalry (I954), 
comparing mother-child relations in Bali and New Guinea, while the other, Bathing Babies in Three Cultures (1954), adds a third dimension by including material shot in the USA as well. Some twenty-five years later, Mead edited a seventh film from the material, though this did not form part of Character Formation series. This was Learning to Dance in Bali and as the title suggests, it deals not with mother-child relations, but with dance instruction, and primarily with that given by a professional performer, a certain Mario, rather than by parents.

Although Mead and Bateson may have set out with the explicit intention of producing objective visual documentation rather than 'documentaries', as this term was understood in the I930s, all seven of the final edited films could be characterised as documentaries in the standard modern sense of term. That is, although they intended to present a factual account of the world as it is in reality, the original footage has clearly been manipulated in the edit suite for the purposes of narrativisation. From a stylistic point of view, however, there is considerable variation between the seven films.

Most of the films consist, in effect, of illustrated lectures by Mead, in which the visual documentation is offered in support of verbal arguments delivered through the soundtrack. Although the material presented in these illustrated lectures sometimes has an intrinsic chronological structure, as for example in A Balinese Family (I95I) and Karba's First Years (1952), this is diffuse and it is primarily Mead's narration that carries the film along. By contrast, in a number of the other films, it is the chronological structure of an intensive event over a limited time period that constitutes the main narrative motor of the film. Although these films also feature a verbal narration by Mead, this is more of a response to the various moments of the evolving event rather than being constitutive of the narrative itself. Such is the case, for example, in First Days in the Life of a New Guinea Baby (I952), where at various points, Mead's voice falls completely silent and the dramatic detail of the event itself takes over the reins of the narrative, as it were.

If the illustrated lecture films look back towards towards the documentation films of Haddon and Spencer, these films with event-based narratives look forward to the film-making praxes of the leading ethnographic documentary film-makers of the immediate post-war period. By far the most elaborate example of the event-led narrative structure among the Mead-Bateson films is Trance and Dance in Bali (1952), which features the tjalonarang theatrical performance. This is the film that departs most from the original documentation footage in that it draws on material shot during two different performances of the event and presents this as if it all formed part of a single event. The narrative arc of the film is also supported by a soundtrack of gamelan music, probably recorded some ten years beforehand, and 'arranged' (as the credits put it) by the then well-known modernist composer, Colin 
McPhee, who was, at the time, married to Jane Belo. The dramatic culminating moments of the tjalonarang, shot by Belo because Bateson had run out of film stock, are shown in slow motion. In combination with McPhee's musical arrangement, this slow-motion effect considerably enhances the viewer's sense of the trance state of the dancers (figure I.I6, right).

In all these respects, Trance and Dance in Bali represented a clear departure from the principle of using the moving image camera merely as a recording instrument. As such, it was clearly at odds not only with Bateson's methodological statement cited above, but also with Mead's frequent later pronouncements about the use of visual media in ethnographic research. It is somewhat ironic therefore that it is for this film that both she and Bateson are most remembered as film-makers. ${ }^{64}$

While, in later years, Bateson appears to have undergone something of change of heart as to the role of the moving image camera in ethnographic research, Mead continued to insist that its main purpose was to serve as an objective recording instrument. As late as I975, in the introductory chapter to the landmark volume, Principles of Visual Anthropology, edited by Paul Hockings, she was still promoting the idea of the moving image camera as analogous to the telescope or the microscope in its ability to enable observations of the world in an entirely objective manner but with the added advantage that it could also record those observations for posterity. She envisaged a utopian future when a fully automated camera with a 360-degree lens could be set up in a central place within a village to record large batches of material without this in any way affecting the customs and behaviour of those being filmed. This filmic data-gathering, she argued, should not involve any sort of selection, either in shooting or in editing. Nor need it be motivated by any theoretical purpose: the important thing was to get it done before the customs being filmed disappeared for ever. ${ }^{65}$

This idea of the moving image camera as analogous to an objective scientific recording instrument has proved remarkably resilient in the history of English-language ethnographic film-making. It is an idea that continues to surface occasionally, even now. Yet notwithstanding its enduring appeal, it is an analogy that should be firmly resisted since it obscures the fact that the creation of a cinematographic image can never be entirely objective given that even in placing a camera and turning it on and off, a film-maker is engaged in a signficant act of authorship. In fact, Mead's dream of a 360-degree camera has recently been realised and is already being used for ethnographic purposes by film-makers in various different parts of the world. But these cameras still have to be placed in certain selected positions as well as turned on and off at certain points, and for these reasons alone, if not for many others, they are no more capable of producing entirely objective accounts of the world than earlier models with a more restricted range of view. 
Rather than thinking of the moving image camera as merely an instrument for recording events in an entirely objective fashion, it is both more appropriate and more productive to think of it as a means for producing an authored representation that ascribes ethnographic significance to those events. For although it might faithfully record what is going on in front of it, a moving image camera cannot by itself determine the significance of what it records, and it is this significance, rather than the mere existence of the phenomena recorded, that is of over-riding importance in any form of ethnographic film-making. What Margaret Mead and many of her generation failed to grasp is that it is the manner in which a film is authored, not the absence of authorship, that ensures its ethnographic qualities.

\section{Notes}

1 de Heusch (2007).

2 www.silenttimemachine.net.

3 A sample of Regnault's material (albeit with the superimposition of a saccharine voice-over in Italian and a Chopin nocturne) is available at www.youtube.com/ embed/IvTRx8UGEV8.

4 See Rony (1996), 2I-73 for an extensive discussion of Regnault's work.

5 Rony (I996), 48, quotes from an article that Regnault published in I923.

6 This film can be viewed at aso.gov.au/titles/historical/torres-strait-islanders/clip I/. Haddon also published an extended textual account of the Malo ceremonies (I9OI, $42-52$ ). For a more detailed discussion of Haddon's film-making, see Henley (2OI3b), 386-40I.

7 Letter from Haddon to Spencer, 23 October 1900. Spencer Papers H2, Pitt Rivers Museum, University of Oxford. Quoted in Dunlop (I979), II2.

8 See Henley (2OI3b), 4OI-2I, for a more extended discussion of Spencer's film-making activities, including his later work in Northern Australia. The original material is conserved in the Australian National Film and Sound Archive in Canberra, but the rights are owned by Museum Victoria in Melbourne, to whom Spencer donated his film material in I9I6. Three extracts from the tjintjingalla material as well as more general information about the ceremony are available at https:// collections.museumvictoria.com.au/articles/6785.

9 The case for interpreting the tjintjingalla as an anti-European millenarian dance is made at some length in Henley (2OI3b), 4I8-2I. For a sceptical view about this interpretation, see Hercus (1980), 7, n.4.

10 MacDougall (20I9), p. I3I.

11 Anon. (1929). Like most contributions to this edition of the manual, the Kinematography entry is unsigned. But Haddon was on the editorial committee and had written the corresponding entry in the previous edition, published in I9I2.

12 See pp. 9-10, I8-20.

13 See, among others, MacDougall (I997) (2019), pp. I34-5; MacFarlane (2010), Kuklick (20I3).

14 Fuhrman (2007), 3.

15 For a description of Weule's film work, see Fuhrmann (2015), I33-48. For a discussion of the films produced by the German Melanesian expeditions as well as links to the films online, see www.silenttimemachine.net.

16 See Hempel (2009), Fuhrmann (2013), 45-5I, and www.silenttimemachine.net/ film-makers/koch-grunberg-theodor/.

17 For further details about Pöch and his films, including links to those that are available on the Web, see www.silenttimemachine.net/film-makers/poch-rudolf/ . 
18 A good example can be found at www.youtube.com/watch?v=a2bdPlcrMX 4. See Schüller (1987) for a technical account of how the synchronisation of the film was achieved.

19 See Morris (1987), I5-I6; Berner (2006), Rassool (20I5). The Austrian institutions that hold San remains are committed to digital repatriation but some physical repatriations have also taken place.

20 These paragraphs on Les Archives de la Planète draw on Castro (2008), Amad (2010) and Werner (2015) as well as on my visits to the Musée Albert-Kahn, where the archives are now held in a restored and repurposed version of Kahn's elegant suburban villa. I am grateful to Mme Valérie Perlès, director of the Museum, for providing me with access to its holdings when it was closed to the general public. See also the Museum's website at: albert-kahn.hauts-de-seine.fr.

21 In these paragraphs on the Aupiais-Gadmer project, I draw on the work of Martine Balard, particularly her book (I999), I87-2 I9, and a more recent article (2007). See also Beausoleil (1996).

22 See particularly Marc-Henri Piault (2000), I09-I3, and Murray Levine (2005). Despite the celebrity of the film, it remains difficult to see because the owners have maintained a very tight control over the rights. For a more general overview of interwar French expedition films in Africa, see Bloom (2006), also Henley (2017), 39-44.

23 Although it is unsigned, there can be litttle doubt that Rouch wrote the entry for $\mathrm{La}$ Croisière noire that appears in the 1967 UNESCO catalogue of films about sub-Saharan Africa which he himself edited (Rouch I967a), 40-I. He also comments on the film in an essay that appears later in the same catalogue (Rouch 1967b), 376-7.

24 For further details see Henley (2017), 42-4.

25 Durosay (1993), 39-40.

26 Bloom (2008), I25-35; Murray Levine (2010), I20-4; Henley (2017), 45-6.

27 Quinn (1980).

28 See Henley (2017), 53-5 and www.silenttimemachine.net.

29 In these paragraphs on Griaule's films, I draw on the work of Éric Jolly (20I4, 20I7)

30 Griaule's comments are reproduced at length by Pierre Leprohon (I945), I85-6.

31 Griaule (1957). Two years later, in 1942, Griaule supervised the release of two further films. These were essentially reversions of the original films, involving some reordering and the incorporation of a few additional sequences. Technique chez les noirs, I5 minutes, covers much the same ground as Au pays des dogons, whereas Le Soudain mystérieux, which runs to I3 minutes, is effectively a reversion of Sous les masques noirs. The voice-over commentaries and musical soundtracks are also different but not markedly dissimilar to those of the original films.

32 In these paragraphs, I draw on an article by O'Reilly himself, originally published in I949, and republished in the catalogue of Pacific ethnographic films edited by Jean Rouch and Monique Salzmann (1970), 28I-7, as well as on an article by Hugh Laracy (2013), and some personal communications from Jean Guiart in August 2018 for which I am very grateful. See also www.silenttimemachine.net.

33 See https://videotheque.cnrs.fr/index.php?urlaction=doc\&id_doc $=403 \&$ rang $=\mathrm{I}$.

34 The films made by the Dutch in their East Indian colonies and by the Belgians in the Congo were similarly primarily concerned with their own modernising activities, though the Dutch were perhaps marginally more active than the British in also making a few films about local indigenous social and cultural life. See the collection of films held by the Eye Film Museum in Amsterdam at www.eyefilm.nl. See also Belgisch Congo Belge the recently released DVD collection of colonial films about the Congo released by the Cinematek of the Royal Belgian Film Archive. In their colonies in Africa, the Portuguese were also primarily concerned as film-makers with their own activities (see De Rosa 20I8).

35 In these paragraphs, I draw on Seton (I935/I97I), Starr (I975/I996), Guynn (I998), Gitlin (2OI2). See also the notes by Jon Hoare on the Colonial Film website at: www.colonialfilm.org.uk/node/486. 
36 This was the principal criticism of my former Manchester colleague and specialist in the anthropology of Sri Lanka, Martin Southwold, as expressed to me in a personal communication when we screened the film together on one occasion in 1988 . However, according to the cinema critic and Indianist, Marie Seton, a contemporary of Wright, the robes of these dancers are said by local people to have been designed by the Buddha two thousand years ago (Seton I935/I97I, I02).

37 See pp. I73 note 4; 285, 396.

38 These paragraphs draw on Dunlop (1979), Batty (2013) and particularly on the archive pages of the South Australia Museum website at archives.samuseum.sa.gov.au/ aa346. See also www.silenttimemachine.net.

39 Dunlop (1979), IIs.

40 For a more extended discussion of this film, see Caiuby, da Cunha and Henley (20I7). It is viewable at www.youtube.com/watch?v=Ein6eKqMBtE\&t=86os.

41 These paragraphs draw extensively on the excellent book by Oksana Sarkisova (2017).

42 See Sarkisova (2017), 40-62.

43 See Sarkisova (2017), 84-90. The film itself can be viewed online in reasonable quality, albeit as part of a Russian television programme at www.youtube.com/ watch?v=ADyG_YRvn6A. I am particularly indebted to Alex and Riita Pravda for the translation of the intertitles of this film. See also www.silenttimemachine.net.

44 Sarkisova (2017), 90-5, I08-II, 208.

45 I am particularly indebted to Peter Whiteley, Curator of North American Ethnology at the American Museum of Natural History, New York, for his review of these paragraphs concerning the films made in Pueblo communities.

46 See Sutton (2017).

47 See Griffiths (2002), I76; Jordan (1992), IIO-I7; Gidley (1982), 73. In Principles of Visual Anthropology, the influential volume edited by Paul Hockings (1993), plate 7 shows a photograph of a Hopi 'snake dance' at Orayvi village in I898. In the background, a man stands over what appears to be a moving image camera. The caption suggests that this is Thomas Edison, but this is impossible, as Edison left it to professional operators to do the actual filming of the films that he produced. Given the date and location, it is more likely to be Oscar Bennet Depue, while the tall man standing beside him could even be Burton Holmes himself. The I9I3 film featuring Roosevelt, probably shot by Emery Kolb, is available via the Library of Congress website at www.youtube.com/watch? $=\mathrm{mfmPGcyV} 7 \mathrm{lM}$.

48 Griffiths (2002), 288-93.

49 This film is no. 192 in the AMNH catalogue and its descriptive title is Hopi Indians of the Southwest and Snake Dance of the gth Day. Peter Whiteley kindly reviewed this film at my request and identified the location as Musangnuvi. He suggests that the film might be an amalgam of footage shot in a number of different Hopi villages since he suspects that the sequence of the man carding wool is Sitsom'ovi village on First Mesa.

50 See de Brigard (I995), 20-I. Hodge is perhaps most remembered today as the principal editor of Edward S. Curtis's photographic encyclopaedia, The North American Indian.

51 This necessarily highly summary account of the shálako ceremony draws extensively on Tedlock (1983).

52 On the internal Zuni politics surrounding this film, see Wenger (2009), I85-7.

53 See ashiwi-museum.org/collaborations/shalako-film-remade/.

54 I regret that I have been unable to see this film on account of the Zuni presence restriction. The complex issues of copyright and control over the new film have been discussed by Anderson and Montenegro (2017).

55 See Martins (2007, 2012).

56 See the Smithsonian website at www.sil.si.edu/expeditions/1926/browse.cfm; also www.silenttimemachine.net. 
57 See King (I993), and, in the listing of filmic references at the end of this book, the two films with the common title Primitive Peoples of Matto Grosso, released in I94I. Although this title is offensive to modern sensibilities, the films themselves are generally respectful of Bororo and Yawalpiti culture. See also Cunha and Caiuby Novaes (20I9) and the references to all the film material arising from the I93I Mato Grosso expedition at: www.silenttimemachine.net.

58 For many years, the Kwakwaka' wakw were referred to in the ethnographic literature as the 'Kwakiutl', a term which is an anglicisation of kwagulth, the name of the particular local group whom Boas primarily studied. Kwakwaka'wakw is a more comprehensive name that has been adopted since the I980s, which is applicable to all the various different local groups who speak the Kwak'wala language (Peter Whiteley, personal communication, September 20I8).

59 In these paragraphs on Boas, I draw on Ruby (I980); Jacknis (I987); Morris (I994), 55-66; Griffiths (2002), 304-9 as well as on my viewing of the Boas footage held by the National Anthropological Film Collection at the Smithsonian Institution. In I972, Boas's material was gathered into a 48-minute documentary and released by the University of Washington under the title The Kwakiutl of British Columbia, but I have been unable to view this.

60 In these paragraphs on Herskovits, I draw on two articles (I990a, I990b) and some personal communications by John Homiak (in May 20I5) as well as on my viewings of Herskovits's films at the National Anthropological Film Collection at the Smithsonian Institution. Herskovits's audio recordings (which I have not had the opportunity to study) are held by the Archives of Traditional Music at the University of Indiana. See www.indiana.edu/ libarchm/.

61 For a more extended discussion of Mead and Bateson's films, see Henley (2013a).

62 Bateson and Mead (1942), 49.

63 Mead and Bateson's theories on this matter, both in relation to the Balinese and in relation to the causes of schizophrenia more generally, are now entirely discredited. See Jensen and Suryani (1992), also Henley (2013a).

64 Trance and Dance in Bali is one of a select group of eight supposedly 'ethnographic' films selected by the National Film Registry for preservation in the US Library of Congress (Durington and Ruby 2011, 205).

65 See Mead and Bateson (1977), Mead (1995), 9-10. 